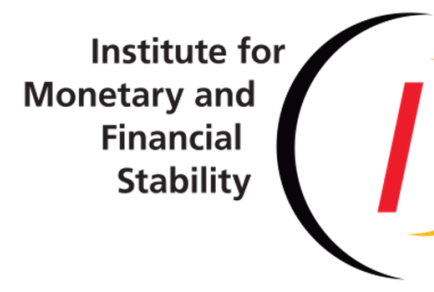

ROBERT C.M. BEYER, LAZAR MILIVOJEVIC

Dynamics and Synchronization of

Global Equilibrium Interest Rates

Institute for Monetary and Financial Stability

GOETHE UNIVERSITY FRANKFURT 
This Working Paper is issued under the auspices of the Institute for Monetary and Financial Stability (IMFS). Any opinions expressed here are those of the author(s) and not those of the IMFS. Research disseminated by the IMFS may include views on policy, but the IMFS itself takes no institutional policy positions.

The IMFS aims at raising public awareness of the importance of monetary and financial stability. Its main objective is the implementation of the "Project Monetary and Financial Stability" that is supported by the Foundation of Monetary and Financial Stability. The foundation was established on January 1, 2002 by federal law. Its endowment funds come from the sale of 1 DM gold coins in 2001 that were issued at the occasion of the euro cash introduction in memory of the D-Mark.

The IMFS Working Papers often represent preliminary or incomplete work, circulated to encourage discussion and comment. Citation and use of such a paper should take account of its provisional character.

\section{Institute for Monetary and Financial Stability}

Goethe University Frankfurt

House of Finance

Theodor-W.-Adorno-Platz 3

D-60629 Frankfurt am Main

www.imfs-frankfurt.de | info@imfs-frankfurt.de 


\title{
Dynamics and Synchronization of Global Equilibrium Interest Rates
}

\author{
Robert C. M. Beyer
}

\author{
Lazar Milivojevic ${ }^{2}$
}

January 2021

\begin{abstract}
With the COVID-19 pandemic, the intense debate about secular stagnation will become even more important. Empirical estimates of equilibrium real interest rates are so far mostly limited to advanced economies, since no statistical procedure suitable for a large set of countries is available. This is surprising, as equilibrium rates have strong policy implications in emerging markets and developing economies as well; current estimates of the global equilibrium rate rely on only a few countries; and estimates for a more diverse set of countries can improve understanding of the drivers. This paper proposes a model and estimation strategy that decompose ex ante real interest rates into a permanent and transitory component even with short samples and high volatility. This is done with an unobserved component local level stochastic volatility model, which is used to estimate equilibrium rates for 50 countries with Bayesian methods. Equilibrium rates were lower in emerging markets and developing economies than in advanced economies in the 1980s, similar in the 1990s, and have been higher since 2000. In line with economic integration and rising global capital markets, synchronization has been rising over time and is higher among advanced economies. Equilibrium rates of countries with stronger trade linkages and similar demographic and economic trends are more synchronized.
\end{abstract}

Keywords: equilibrium interest rate, stochastic volatility, Bayesian inference, synchronization

JEL Classification: E52, E43, C32

\footnotetext{
${ }^{1}$ Robert C.M. Beyer, The World Bank

${ }^{2}$ Lazar Milivojevic (Corresponding Author), Institute for Monetary and Financial Stability, Goethe University Frankfurt, House of Finance Office 4.57, Theodor-W.-Adorno-Platz 3, 60629 Frankfurt am Main, Germany, lazar.milivojevic@hof.unifrankfurt.de

* This paper has benefited greatly from comments by Hans Timmer, Volker Wieland, Daniel Buncic, Martin Iseringhausen, Mátyás Farkas, Maik Wolters, and participants of the Mathematical and Statistical Methods for Actuarial Sciences and Finance (eMAF) Conference (Ca' Foscari University of Venice).
} 


\section{Introduction}

This paper proposes a statistical procedure to estimate equilibrium interest rates for a large set of countries, compares equilibrium rates between advanced economies and EMDEs, and explains their synchronization over time. Equilibrium (natural) real interest rates and their implications for economic policy have attracted strong academic and policy interest in recent years. The discussion gained momentum when GDP growth and interest rates did not recover as much as expected after the global financial crisis and concerns about a secular stagnation rose (Summers 2014). The sustained extraordinarily low interest rates in advanced economies suggested that the equilibrium rate of interest had declined. There has been a lot of focus on the decline in equilibrium interest rates in the United States, which is confirmed across varying equilibrium definitions and estimation strategies (Hamilton et al. 2016, Kiley 2015, Lubik and Matthes 2015, Johannsen and Mertens 2016, Juselius et al. 2016, Laubach and Williams 2016). The policy implications of lower equilibrium interest rates are immense. For example, it limits the role of interest rates as a monetary policy tool to stabilize business cycles. Since central banks hit the zero lower bound more often, more extensive use of unconventional policy instruments and fiscal policy is required. In addition, low rates fuel riskier investments as a result of search-for-yield behavior with implications for macro- and micro-prudential policies. With the COVID19 pandemic, the debate about equilibrium interest rates is becoming even more important. On the one hand, higher government borrowings and higher capital needs to adjust to the new environment may increase equilibrium rates again. On the other hand, permanently lower private demand as well as higher precautionary savings and higher risk premia on safe assets may lower rates even further (Goy and van den End 2020).

So far, the focus has been very much on advanced economies and very little effort has been put in estimating equilibrium real interest rates for a larger set of countries. This is surprising for three reasons: first, the dynamics of equilibrium interest rates in emerging markets and developing economies (EMDEs) have important economic policy implications in these countries as well; second, estimates of the global equilibrium rate and our understanding of co-movements of equilibrium rates across countries can be improved by including more countries; and, third, the determinants of equilibrium real rates have often been estimated with a restricted set of countries subject to common trends. ${ }^{1}$ A larger set of countries, however, offers much more variation to pin down the drivers. For example, many advanced economies share similar trends in demographics and growth, but there are large differences with other countries.

We propose a statistical procedure suitable to estimate equilibrium interest rates for a large set of countries. Using our proposed methodology, we estimate equilibrium interest rates for 50 countries from 1970 until 2019. We then construct a global equilibrium rate and show that estimates are robust to different model specifications. ${ }^{2}$ Next, we document important differences in the dynamics between advanced economies and EMDEs and, finally, we use the full set of countries to analyze co-movements between equilibrium rates over time.

\footnotetext{
${ }^{1}$ The same is true for studies of real returns in general. Del Negro et al. (2019) and Gourinchas and Rey (2019), for example, study the connection between real returns, consumption, and wealth and claim to take a global perspective, but the former is based on only seven countries, the latter on only four countries.

${ }^{2}$ For some of them the starting period is after 1970.
} 
Our statistical procedure extracts appropriate time trends from real interest rates even with short samples and high volatility. Equilibrium interest rate estimates from the seminal Laubach-Williams model (Laubach and Williams 2003) are very imprecise even for advanced economies. This is both due to a weak relationship between the output gap and the real interest rate gap and due to a weak relationship between inflation and the output gap. If these relationships are very weak, their model is unobservable and the equilibrium interest rate cannot be uniquely identified (Hamilton et al. 2016, Fiorentini et al. 2018). Those cases are already common for advanced economies, but the identification challenges are even more severe for EMDEs. First, many of them report only annual data, which makes it even harder to find a strong relationship between these variables and, second, EMDEs are more likely to have structural breaks in their data. Fiorentini et al. (2018) show that if the interest rate gap is assumed to be stationary, the Laubach-Williams model can identify the equilibrium interest rate even when the relationships between the output gap, the interest rate gap, and inflation are weak. They also show that from this assumption it follows directly that the equilibrium real interest rate can be estimated with a univariate local level specification model that decomposes the ex-ante real interest rate into its permanent and transitory component. Instead of $\mathrm{ARCH}$, we use a stochastic volatility model to allow for time-varying variance of the interest rate gap and estimate it with Bayesian methods, which is more suitable for EMDEs.

Our study contributes, first and foremost, to the large literature on estimating equilibrium interest rates. The equilibrium rate of interest is a theoretical concept and cannot be observed. The most prominent methodology to estimate it, based on a semi-structural model of Laubach and Williams (2003), provides only very imprecise estimates and even minor modifications of the model or the estimation strategy can result in very different estimates of equilibrium interest rates. ${ }^{3}$ In addition, it is not suited for the estimation of equilibrium real rates in EMDEs due to its data requirements and the need for a strong relationship between the variables included in the model. Recent advances have concentrated on the following areas: first, estimation procedures have been extended and improved for the United States; ${ }^{4}$ second, they have been applied to more advanced economies, $;^{5}$ and, third, equilibrium interest rates for some advanced economies have been constructed for much longer time periods. ${ }^{6} \mathrm{We}$ contribute to this literature by offering an estimation method that allows to extend the estimation of equilibrium rates to many more countries, which to the best of our knowledge is yet missing. ${ }^{7}$

Second, we add to the literature on the global interest rate. Current estimates of the global interest rate are mostly based on small sets of countries: King and Low (2014) present a "world" real interest rate based on data from the G7 countries and Del Negro et al. (2019) interpret the common trend of a VAR model estimated for the same seven economies as the "global" interest rate. While these countries constitute a large share of the world economy, they still provide only a limited understanding of the global interest rate. Wynne and Zhang (2018) add the BRICS countries to their estimation of a global

\footnotetext{
${ }^{3}$ Among others, this is shown in Clark and Kozicki (2005), Kiley (2015), Lewis and Vazquez-Grande (2017), Brand et al. (2018), and Beyer and Wieland (2019).

${ }^{4}$ Examples include Holston et al. (2017), Del Negro et al. (2017), Christensen and Rudebusch (2017), and Krustev (2019).

${ }^{5}$ Examples include Mendes (2014), Fujita and Fujiwara (2016), Belke and Klose (2017), Hledik and Vlcek (2018), and Beyer and Wieland (2019).

${ }^{6}$ Examples include Hamilton et al. (2016), Fiorentini et al. (2018), and Schmelzing (2020).

${ }^{7}$ The only exceptions are Klose (2020) and Wynne and Zhang (2018), who estimate equilibrium rates for the BRIC countries with the Laubach-Williams model. This is only possible because these countries have good quarterly data, which is not the case for most other EMDEs.
} 
equilibrium interest rate and reveal that the global rate changes considerably when these countries are included. This points to considerable differences between the rates in advanced economies and EMDEs. Including more countries benefits studying the dynamics and drivers of global equilibrium rates as it, first, refines the estimation of the global equilibrium interest rate and, second, helps to avoid confounding idiosyncratic specificities with underlying global economic factors.

The paper is structured as follows. Section II reviews related literature and Section III discusses the methodology and data. Section IV presents the main results and robustness checks and Section V compares co-movements of equilibrium rates over time. Section VI concludes.

\section{Literature}

The natural rate of interest goes back to Wicksell (1898) who defined it as the rate that "equates the monetary (or bank loan) rate determined by the financial sector with the equilibrium rate in the capital market (the latter equating the supply and demand for real capital goods)" and was integrated into modern macroeconomic theory by Woodford (2003). He built on the Real Business Cycle literature and defined the equilibrium interest as the rate of interest that would balance aggregate demand and the level of output if prices were fully flexible. ${ }^{8}$ Laubach and Williams $(2003,2016)$ define the equilibrium interest rate as the rate of interest that brings output to potential and inflation to target absent any transitory shocks. ${ }^{9}$ It abstracts from short-term movements and hence reflects secular drivers. Their semi-structural model has been varied and extended in numerous ways. For example, Holston et al. (2017) propose improvements to the estimation and Krustev (2019) adds financial cycles. Hledik and Vlcek (2018) use the approach in a fully-fledged multi-country model for the euro area. ${ }^{10}$ Estimates have also been provided for other advanced economies (Mendes 2014, Fujita and Fujiwara 2016, Belke and Klose 2017, Beyer and Wieland 2019). As already pointed out by Laubach and Williams (2003), these estimates are highly imprecise (Clark and Kozicki 2005, Kiley 2015, Lewis and Vazquez-Grande 2017, Beyer and Wieland 2019, Brand et al. 2018). Others provided alternative estimates based on more complex models. Christensen and Rudebusch (2017), for example, have extracted estimates from a macro-financial model and Del Negro et al. (2019) discuss the equilibrium real interest rate in a DSGE model. ${ }^{11}$ Kiley (2015) considers credit conditions in his estimations of the equilibrium interest rate in the United States and finds a weaker decline than without incorporating them. Similarly, Krustev (2019) incorporates the financial cycle in the Laubach-Williams approach and finds that deleveraging after the global financial crisis has lowered the US equilibrium rate by one percentage point. ${ }^{12}$ Fiorentini et al. (2018) and Jorda et al. (2020) go the other way and simplify the estimation: they use a univariate local level specification model based on the reasonable assumption of a stationary interest rate gap. Hamilton et al. (2016) and Schmelzing (2020) interpret long-run interest rates as equilibrium rates and put recent changes in a historical perspective. Hamilton et al. (2016) provide estimates for some advanced

\footnotetext{
${ }^{8}$ Similarly, there is a concept of the equilibrium real interest rate in DSGE and overlapping generation models (OLGs), which feature a core inherited from the RBC models.

${ }^{9}$ The equilibrium plays an essential role in the relationship between an IS equation and a Phillips curve, which together explain the evolution of the output gap and inflation.

${ }^{10}$ Other examples are described in detail in Brand et al. (2018).

${ }^{11}$ In DSGE models the natural rate is very volatile and corresponds to a short-term definition (Beyer and Wieland 2019).

${ }^{12}$ Both studies provide evidence that the omission of financial variables biases $r *$ estimates as hypothesized in Juselius et al. (2016), Cukierman (2016), and Taylor and Wieland (2016).
} 
economies going back to 1850 and show that negative rates occurred before. Schmelzing (2020) is advancing the timeline backward even more and provides estimates going back to the 13th century.

Many studies show a strong co-movement of long-term interest rates in many countries with long-term interest rates in the United States over the post-war period (Kulish and Rees (2011), Wright 2011, Dahlquist and Hasseltoft 2013, Swanson and Williams 2014, and Jotikasthira et al. 2015) pointing to important global trends. In line and as implied by economic theory, equilibrium interest rates co-move across countries as well. Holston et al. (2017) find a strong interdependence of equilibrium rates across advanced economies. In the euro area, for example, shocks to the equilibrium rate in the United States are a major source of variation in the long-run and even in the United States a fifth of variance is emanating from other economies. Rachel and Smith (2015) also concur that despite a lot of variation across countries, the presence of a discernible common trend suggests important global factors.

\section{Methodology and data}

\section{a. Estimating equilibrium interest rates for many countries}

As mentioned, Laubach-William estimates are highly imprecise (Clark and Kozicki 2005; Kiley 2015; Lewis and Vazquez-Grande 2017, Beyer and Wieland 2019). Due to large filter uncertainty, their approach cannot estimate the equilibrium interest rate accurately when either the IS curve or the Phillips curve is flat. In those situations, Fiorentini et al. (2018) suggest using a local level specification to derive the equilibrium interest rate from the real interest rate. Building on their approach, we propose a methodology better suited to a large set of countries with data that are in many cases very volatile and only available for short time periods. Our concept of the equilibrium interest rate as the low-frequency components of real interest rates assumes that actual real rates converge to their equilibrium counterparts and excludes the possibility that the effective and equilibrium real rates diverge for long periods (Levrero 2019).

\section{b. The model}

We estimate equilibrium interest rates with a univariate local level model which decomposes the real interest rate into its permanent (equilibrium rate $r^{*}$ ) and transitory (interest rate gap $\widetilde{\mathrm{r}}$ ) component, building on Fiorentini et al. (2018). Such a univariate local level model follows directly from the semistructural model of Laubach and Williams (2003) with the additional assumption of a stationary interest rate gap. We hence assume that deviations between the real interest rate and its unobserved permanent component are temporary. ${ }^{13}$ The permanent component of the real interest rate can be considered a measure of $r^{*}$. We use ex-ante real interest rates, defined as the difference between the nominal shortterm interest rate and expected inflation. For the latter, we construct expected inflation from a forecast of a sequence of $\mathrm{AR}(1)$ models on realized inflation rates with rolling windows of 20 years, following the usual approach in the literature (Hamilton et al. 2016, among others). ${ }^{14}$

More specifically, we estimate an unobserved component local level stochastic volatility model on the real interest rate for each country $i$ using the following specification:

\footnotetext{
${ }^{13}$ This is also in line with the New Keynesian modeling literature, where in the steady state the interest rate gap is 0 , output at its potential and inflation equal to its target.

${ }^{14}$ In the robustness checks, we compare the results of using ex-ante real interest rates with ex-post interest rates and find only minor differences.
} 


$$
\begin{gathered}
r_{i t}=r_{i t}^{*}+\widetilde{r_{l t}}, \\
r_{i t}^{*}=r_{i t-1}^{*}+e_{i t}, e_{i t} \sim N\left(0, \sigma_{e_{i}}^{2}\right), \\
\widetilde{r_{t t}}=\varepsilon_{i t} \sqrt{e^{\ln h_{i t}}}, \varepsilon_{i t} \sim N(0,1), \\
\ln h_{i t}=\alpha_{0 i}+\alpha_{1 i} \ln h_{i t-1}+v_{i t}, v_{i t} \sim N\left(0, \sigma_{v_{i}}^{2}\right),
\end{gathered}
$$

where the real interest rate is the sum of $\mathrm{r}^{*}$ and the interest rate gap $\widetilde{r_{t}}$ (equation 1), the equilibrium rate is represented by a random walk (equation 2), the interest rate gap features stochastic volatility (equation 3) where the logarithm of the latent parameter $h_{t}$ is assumed to follow a stationary process $\left|\alpha_{1}\right|<1$ (equation 4). In order to capture large fluctuations of real interest rates in EMDEs, we allow for time-varying variance of the interest rate gap. For that reason, we use a stochastic volatility model and assume two error processes $\left(e_{t}\right.$ and $\left.v_{t}\right)$ - in both permanent and temporary components. The flexibility of stochastic volatility models enables them to capture uncommon volatility behavior observed in certain times series and produces richer dynamics in comparison with GARCH-type models (Canova 2011). Furthermore, they often provide a better approximation of the data-generating process for financial and economic data (Hsieh 1991, Danielsson 1994, Kim et al. 1998, Chan and Grant 2016).

\section{c. The estimation procedure}

The use of maximum likelihood estimation methods, like quasi-likelihood and GMM, is asymptotically correct, but these estimators have poor small sample properties (Jacquier et al. 1994, Kim et al. 1998). Therefore, we rely on a Bayesian approach and Markov chain Monte Carlo (MCMC) methods to estimate the unobserved state variable $\mathrm{r}^{*}$, the stochastic volatility, and the unknown parameters of the model. Given their better estimator performance and the progress with implementing computationally intensive methods, they have become increasingly popular (Jacquier et al. 1994, Kim et al. 1998). A similar methodology has been used in numerous studies to distinguish trend and cyclical components, for example for inflation (Stock and Watson 2007, Grassi and Proietti 2008, Li and Koopman 2018) and GDP (Morley et al. 2003, Blonigen et al. 2014).

In setting our priors, conditional variances are assumed to follow inverse gamma distributions:

$$
\begin{gathered}
\sigma_{e_{i}}^{2} \sim I G\left(\varphi, s_{e}^{2}\right), \\
\sigma_{v_{i}}^{2} \sim I G\left(\varphi, s_{v}^{2}\right),
\end{gathered}
$$

where the scale hyperparameter $s$ represents beliefs regarding the amount of variations in the innovations and the degrees of freedom hyperparameter $\varphi$ corresponds to the strength of those beliefs. We choose the priors such that variation in stochastic volatility is favored over variation in the equilibrium interest rate equation by setting the former to be twice the size of the latter. Additionally, we set the degrees of freedom to be equal to the sample size. In this way, we assume that the motion of r* is subject to more gradual structural and institutional changes, while short-term cyclical fluctuations are captured by stochastic volatility. 
For the autoregressive coefficients, we specify standard priors:

$$
\alpha \sim N\left(0_{2 \times 1}, I_{2 \times 2}\right) .
$$

For the estimation, we rely on the combination of Matropolis-Hastings and Gibbs sampling algorithms. Given that the observation equation in the state space model is non-linear, we employ the independence MH algorithm suggested by Jacquier et al. $(1994,2004)$. The unobserved component $r^{*}$ is estimated by the Carter and Kohn (1994) algorithm.

Broadly following Blake and Mumtaz (2015), we use a 5-step procedure to approximate the marginal posterior distributions. In an initial step, we sample $h_{t}$ conditional on $\mathrm{r}^{*}, \sigma_{e}^{2}, \alpha_{0}, \alpha_{1}$, and $\sigma_{v}^{2}$ starting values, using the Jacquier et al. (1994) algorithm. Given a draw for $h_{t}$, we, second, compute residuals $v_{t}$ and draw $\sigma_{v}^{2}$ from the respective IG distribution. Afterwards, we sample $\alpha_{0}$ from the Normal distribution and $\alpha_{1}$ from the truncated Normal distribution, assuming the stationarity of the $\operatorname{AR}(1)$ process. In the fourth step, the Carter and Kohn (1994) algorithm is used to sample r* conditional on the other parameters. The usual Kalman filter is extended in this case in order to take into account that the variance of the observation equation is different at each point in time. Finally, $\sigma_{e}^{2}$ is sampled from its respective IG distribution, conditional on $\mathrm{r}^{*}$.

For the starting values, we assume that equilibrium rates and real interest rates are equal. The sampler is run for 100,000 draws, given the concerns that a single-move algorithm may require a large number of draws to converge (Kim et al. 1998). We discard the first 80,000 draws as burn-in and save every 20th draw to limit their autocorrelation. That leaves us with 1,000 draws used for inference. The satisfactory convergence of the sampler is confirmed via visual inspection of the draws, the recursive means and the autocorrelations of the parameters and state variables. ${ }^{15}$

\section{d. The data}

We construct an unbalanced panel at annual frequency from 1970 to 2019 for a set of 50 countries, of which 23 are advanced economies. ${ }^{16}$ Data on nominal short-term interest rates and CPI inflation rates for most of the advanced economies come from the Jordà-Schularick-Taylor (2017) Macrohistory Database, which we extend with data from the IMF IFS database or respective individual country sources. For the rest of our sample, we rely mostly on interest rate data from the IMF IFS and the OECD and on data on CPI inflation or GDF deflators from the World Bank WDI. When the central bank policy rate is not available, we use discount, money-market, or treasury bill rates instead. Detailed information about the countries included and the data sources for each country is included in Appendix A. Data for the analysis of the drivers of synchronization are from the UN population statistics (ratio of young to working-age population), UN Comtrade (bilateral trade), and the World Bank (GDP growth and inflation).

\footnotetext{
${ }^{15}$ Results are available upon request.

16 The following countries are the subject of our analysis: Austria, Australia, Barbados, Bangladesh, Belgium, Burundi, Botswana, Belize, Canada, China, Colombia, Germany, Guyana, Denmark, the Republic of Egypt, Finland, France, the Gambia, Greece, Guyana, Hungary, Indonesia, Ireland, India, Italy, Japan, Jordan, the Republic of Korea, Kuwait, Lesotho, Morocco, Mauritania, Mauritius, Mexico, Malaysia, the Netherlands, Norway, New Zealand, Oman, the Philippines, Pakistan, Portugal, Singapore, South Africa, Spain, Sweden, Switzerland, Thailand, Trinidad and Tobago, the United Kingdom, and the United States. Several emerging market countries with an increasing role in the global economy (Brazil, Poland, the Russian Federation, Turkey, and others) are not included because of data unavailability or numerous extreme events.
} 
We replace missing values and large outliers of observed real interest rates with predictions from a Kalman smoother based on local level models. Broadly following Fiorentini et al. (2018) and Probst (2019), we identify observed real interest rates above 20 percent in absolute terms as outliers. The outlier removal, and the specific threshold in particular, has only a minimal effect on the estimates of $\mathrm{r}^{*}$, but ensures convergence of the model. ${ }^{17}$ Table 1 shows the total number of observations in our sample, as well as the share of outliers and missing values.

Table 1 Sample characteristics

\begin{tabular}{lc|cc} 
& Full Sample & $\begin{array}{c}\text { Advanced } \\
\text { economies }\end{array}$ & EMDE \\
\hline \hline Number of countries & 50 & 23 & 27 \\
Observations & 2318 & 1129 & 1189 \\
Outliers (\%) & 1.12 & 0.09 & 2.1 \\
Missing (\%) & 0.13 & 0 & 0.25 \\
\hline
\end{tabular}

In Table 2 we provide summary statistics for the main variables over the whole period and during different episodes - the post-war period, the Great Moderation, and the Great Recession and its aftermath. As expected, both nominal interest and inflation rates were highest in the period before the Great Moderation, with quite similar values between advanced economies and EMDEs. In both ex-ante real interest rates were negative, though more so in EMDEs. In advanced economies both the average nominal interest rates and differences across countries decreased significantly afterwards. Since inflation declined even more, ex-ante real interest rates increased to 2.7 percent on average between 1984 and 2007. In EMDEs, nominal interest rates increased while inflation decreased, resulting in similar average ex-ante real interest rates of 3.1 percent during this period. With the global financial crisis, nominal interest rates in advanced economies dropped strongly from 6.6 percent between 1984 to 2007 to only 0.8 percent between 2008 and 2019. At the same time, inflation declined only from 3.4 percent to 1.5 percent, resulting in negative ex-ante real interest rates. There has been a similar trend in EMDEs, but their average ex-ante real rates remained positive during this period. Over the entire sample, ex-ante real rates have been 1.0 percent in advanced economies and 1.6 percent in EMDEs, with both nominal interest rates and inflation much higher in EMDEs.

\footnotetext{
${ }^{17}$ In the robustness section, we show that inferring $\mathrm{r}^{*}$ from the observed real interest rate without replacing missing values and outliers leads to very similar results.
} 
Table 2 Summary statistics

\begin{tabular}{lllcc|cc|cc} 
& & \multicolumn{3}{c}{ Nominal interest } & \multicolumn{2}{c}{ Inflation } & \multicolumn{2}{c}{ Ex-ante real rate } \\
\hline \hline & & & AE & EMDE & AE & EMDE & AE & EMDE \\
Post-war & \multirow{2}{*}{$1970-1983$} & mean & 9.3 & 8.9 & 10.1 & 11.8 & -0.3 & -1.7 \\
period & & st.d. & 4.1 & 5.9 & 5.9 & 11.8 & 3.9 & 4.4 \\
Great & \multirow{2}{*}{$1984-2007$} & mean & 6.6 & 12 & 3.4 & 9.1 & 2.7 & 3.1 \\
moderation & & st.d. & 4.6 & 9.1 & 3.3 & 13.8 & 2.5 & 4.4 \\
Great recession & \multirow{2}{*}{$2008-2019$} & mean & 0.8 & 6.6 & 1.5 & 4.8 & -1.0 & 1.3 \\
and aftermath & & st.d. & 1.4 & 3.9 & 1.4 & 4.2 & 1.2 & 3.5 \\
\multirow{2}{*}{ Full sample } & \multirow{2}{*}{$1970-2019$} & mean & 5.9 & 9.9 & 4.8 & 8.5 & 1.0 & 1.6 \\
& & st.d. & 5 & 7.8 & 5.1 & 11.8 & 3.2 & 4.5 \\
\hline
\end{tabular}

Note: AE stands for advanced economies.

\section{Results}

\section{a. Equilibrium interest rates at the country level}

We estimate the equilibrium interest rate for 50 countries from 1970 or from whenever the necessary data are available. We plot all results in Appendix A2 and the data series are available upon request. Interest rate volatility varies both in advanced economies and EMDEs. However, as expected, it is more volatile in EMDEs and was especially high in the first half of the 1980s and the 1990s. ${ }^{18}$

\section{b. The global equilibrium interest rate}

The global equilibrium interest rate anchors equilibrium rates in countries that are economically open. It can be thought of as the equilibrium rate to which country-specific rates would converge in the longrun if there were no distortions or shocks. It is determined by expectations of global trend growth and other factors determining desired savings and investment. Among the factors driving equilibrium rates away from this rate are both global and country-specific temporary factors (Rachel and Smith 2015). ${ }^{19}$

Figure 1 shows the global equilibrium interest rate from 1983 until 2019, defined as the GDP weighted average of all countries other than China, for which data are only available from 1990 onward. ${ }^{20}$ In the 1980s, the global equilibrium interest rate was around 3 percent, which was relatively high, consistent with the economic boom resulting in high global fixed investment. The global equilibrium rate peaked in 1989 when it was just above 3.5 percent. Subsequently in the 1990s it declined slowly but steadily. From 2000 to 2004, the downward trend became much steeper and the global equilibrium interest rate dropped from around 2.0 percent in 2000 to below 0.5 percent in 2003. It remained low in the following years and took another hit due to the global financial crisis. It plunged to negative territory in 2009 and declined further to a minimum of almost -1.0 percent in 2013. Since then it recovered only slightly and in 2019, the last year in the sample, it stood at -0.5 percent. The uncertainty around the estimates is not larger than for many other estimation strategies, despite this sample including many EMDEs. The

\footnotetext{
18 The average time-varying volatility across advanced economies and EMDEs is plotted in Appendix A3.

${ }^{19}$ For a detailed discussion of how the global equilibrium rate is related to country-specific equilibrium and policy rates, refer to Rachel and Smith (2015).

${ }^{20}$ GDP values in constant 2010 US\$ come from the World Bank and OECD national accounts data. China is included in a robustness check in section 4.3.
} 
shaded area in Figure 2 shows the 90-percent credible interval that is around 2 percentage points wide throughout the sample, declining slightly in the last two decades.

Figure 1 The global equilibrium real interest rate

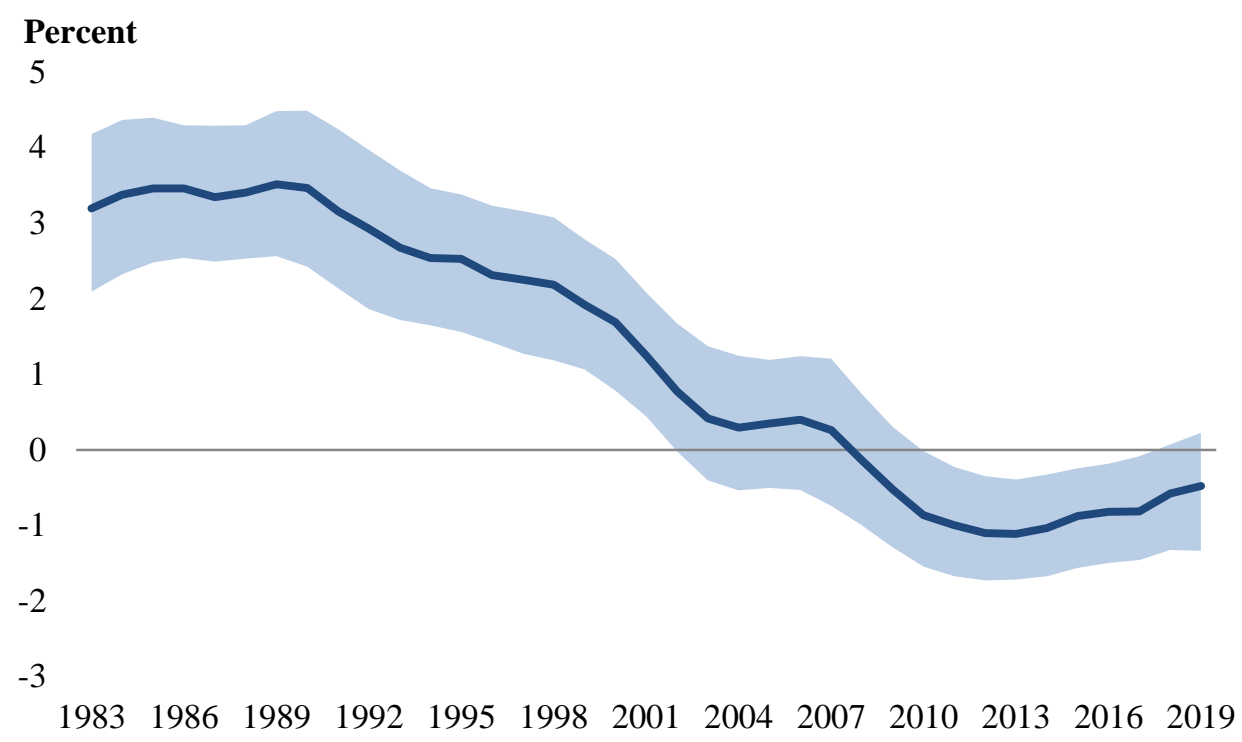

Note: The dark blue line shows the GDP weighted equilibrium interest rates. The light blue band shows the 90-percent credible interval.

\section{c. Robustness}

We perform several robustness checks to validate the global aggregation and our main estimation procedure. We present the alternative results in Figure 2, together with the benchmark result. Adding China to the sample results in only a minimally higher global equilibrium rate after 1990. Next, we replace the estimated ex-ante interest rates entering the model with ex-post observed interest rates, calculated as a difference between nominal rates and observed inflation. While the main trends remain the same, there are some differences. The equilibrium rate based on ex-post rates was somewhat higher in the 1980s and 1990s. It peaked at 4.3 percent, compared to 3.5 percent for the equilibrium rate based on ex-ante rates. In an additional estimation, we do not replace outliers and missing data points. Instead, they are excluded from the analysis and not used to update the information within the Kalman filter. ${ }^{21}$ This enables us to address potential concerns regarding the method used to replace missing values in the sample. But the results are nearly identical, and differences are not visible.

In our estimation we need to choose priors that then determine the amount of variation in our components. We experimented with different priors and found that overall trends are robust to a wide range of priors. Naturally, more diffuse priors allowing for substantially larger fluctuations in components result in more volatile equilibrium rates. ${ }^{22}$

\footnotetext{
${ }^{21}$ This is based on the approach described in Mariano and Murasawa (2003).

22 Results available upon request.
} 
Figure 2 The global equilibrium real interest rate - robustness checks

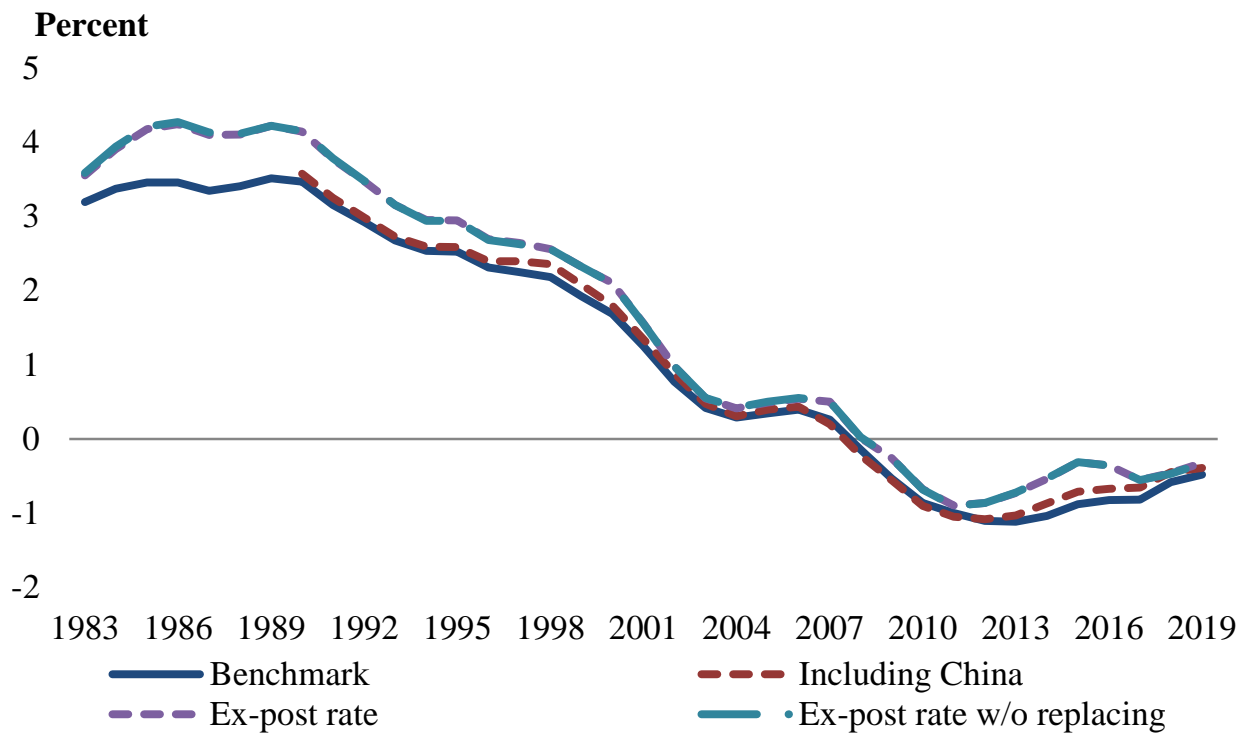

\section{d. Equilibrium interest rates in advanced economies and EMDEs}

Equilibrium rates of course follow different paths in different countries. One potentially useful categorization is to focus on differences between advanced economies, which are economically and financially more integrated, and EMDEs, which are still integrating themselves into the world economy. Figure 3 shows the equilibrium real interest rates for these two groups separately. While the advanced economies are in the minority in numbers, they account for a higher share of global gross domestic product (GDP) than EMDEs. It is hence not surprising that the shape of the equilibrium rate in advanced economies is very similar to the one for the world shown in Figure 1. The equilibrium interest rate in EMDEs, on the other hand, shows some specificities: first, their rates were lower in the 1980s; second, they declined slower in the 1990s; third, while it declined during the global financial crisis as well, it went below zero only briefly and started recovering faster and stronger. In 2019, the last observation of the sample, the rate stood at -0.9 percent in advanced economies but at 0.5 percent in EMDEs.$^{23}$ Over the last 20 years, the equilibrium interest rate in EMDEs was higher than in advanced economies.

${ }^{23}$ The divergence between advanced economies and EMDEs has already been noticed by Rachel and Smith (2015), who analyze the nominal yield on 10-year sovereign bonds minus 1-year-ahead inflation expectations in 17 emerging markets. 
Figure 3 The equilibrium real interest rate in advanced economies and EMDEs

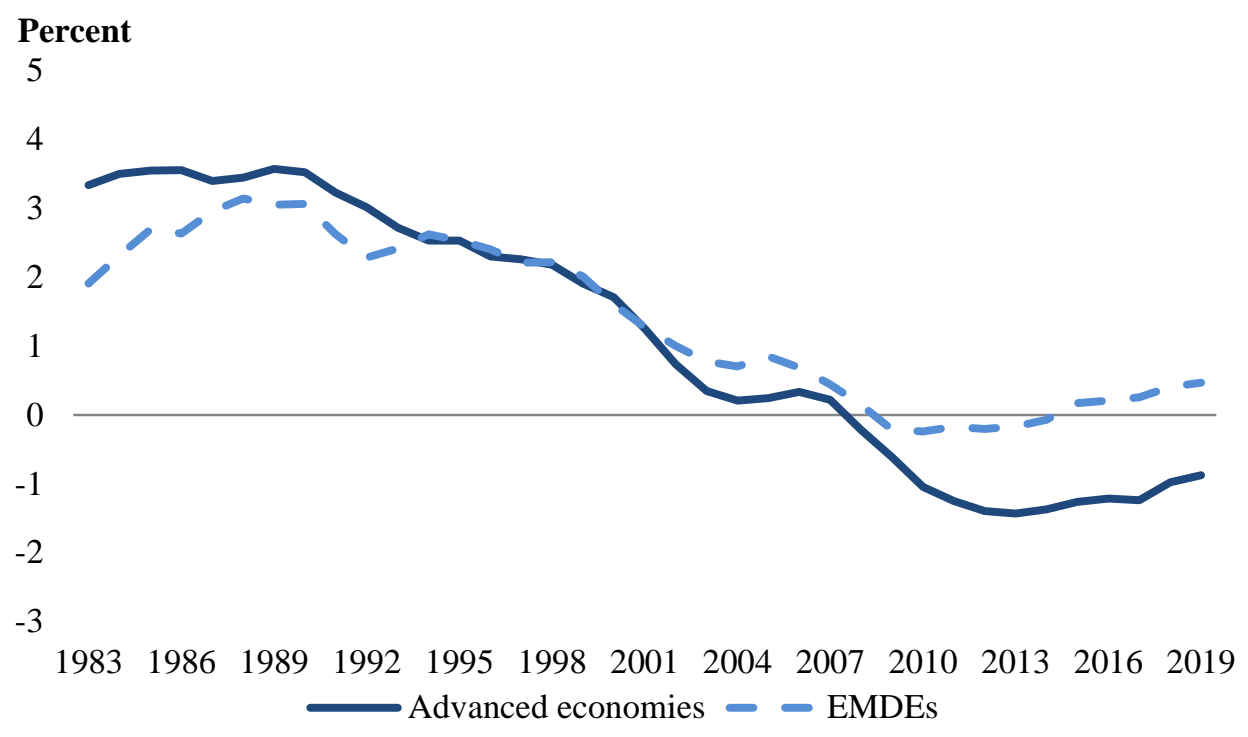

\section{Co-movement of equilibrium interest rates across countries}

\section{a. Synchronization}

Next, we analyze co-movements between equilibrium interest rates. To do so, we rely on a standard synchronization measure from the GDP growth literature (Morgan et al. 2004, Giannone et al. 2008, Kalemli-Ozcan et al. 2013, Cesa-Bianchi et al. 2019, among others). We define $S_{i j, t}$ as the absolute bilateral differential in $r^{*}$ changes:

$$
S_{i j, t}=-\left|\Delta r_{i, t}^{*}-\Delta r_{j, t}^{*}\right|,
$$

where $\Delta r_{i, t}^{*}$ and $\Delta r_{j, t}^{*}$ are the first differences of the equilibrium real interest rates in countries $i$ and $j$ at time $t$. According to its definition, $S_{i j, t}$ increases with the degree of synchronization, with negative values close to zero between countries that are more synchronized. Given our random walk assumption for the equilibrium interest rate dynamics, this is equivalent to considering the synchronization between the permanent shocks to $r^{*}$ in two countries.

Although this measure is preferable to the Pearson correlation coefficient, since it is invariant to the volatility of the underlying shocks (Forbes and Rigobon 2002, Corsetti et al. 2005), it still has some ambivalent properties. Even if equilibrium rates in two countries move in the same direction, so that co-movement is high, $S_{i j, t}$ can still fall if the magnitude of those responses differs across the countries. In other words, $S_{i j, t}$ conflates co-movement and dispersion. ${ }^{24}$ Against this background, Cesa-Bianchi et al. (2019) propose an extension to control for the existence of common shocks with country-specific effects. They suggest two additional measures based on the straightforward assumption that the variable of interest is impacted by a vector of common shocks $\mathrm{F}_{t}$ with heterogeneous country loadings $b_{i}$ :

$$
\Delta r_{i, t}^{*}=a_{i}+l_{i} \mathrm{~F}_{t}+\varepsilon_{i, t},
$$

\footnotetext{
${ }^{24}$ See Cesa-Bianchi et al. (2019) for a more detailed discussion.
} 
where $a_{i}$ is the average change of $\Delta r_{i, t}^{*}$ in country $i, \varepsilon_{i, t}$ stands for the $\Delta r_{i, t}^{*}$ response to an idiosyncratic shock, and $l_{i}$ denotes the vector of country $i$ loadings on a $f \times 1$ vector of common (to at least two countries) factors $F_{t}$.

Therefore, one can distinguish between the international propagation of idiosyncratic (country-specific) shocks:

$$
S_{i j, t}^{\varepsilon}=-\left|\varepsilon_{i, t}-\varepsilon_{j, t}\right|
$$

and the international equilibrium responses to common shocks:

$$
S_{i j, t}^{\mathrm{F}}=-\left|\left(l_{i}-l_{j}\right) \mathrm{F}_{t}\right| .
$$

Figure 4 shows the evolution of the average values of $S_{i j, t}, S_{i j, t}^{\varepsilon}$ and $S_{i j, t}^{\mathrm{F}}$ for the fully balanced panel from 1984 to $2019 .{ }^{25} \mathrm{~F}_{t}$ is proxied by the first 8 principal components on the full panel of $\Delta r_{i, t}^{*} \cdot{ }^{26}$ The upward slope of the average synchronization measure indicates a convergence in equilibrium interest rate dynamics over time, in line with economic integration as well as the creation and rise of global capital markets that allow for a transfer of savings across countries.

Figure 4 Synchronization of equilibrium interest rates

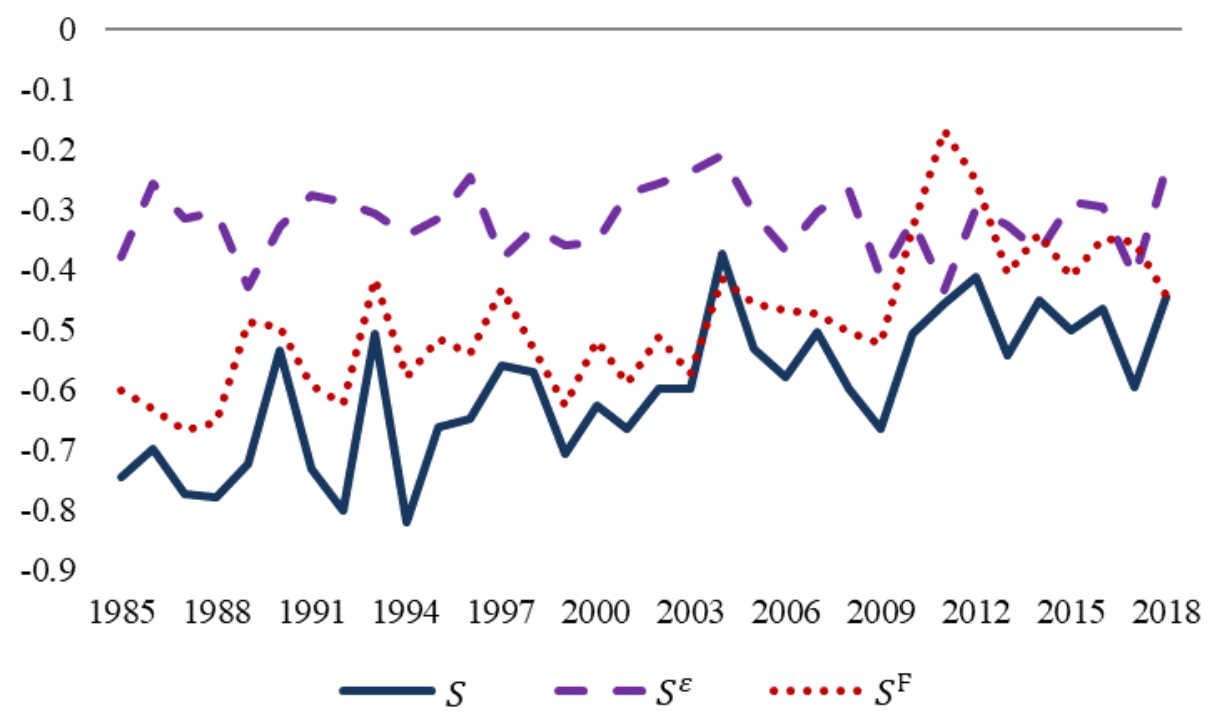

The high correlation (0.82) between $S_{t}$ and $S_{t}^{\mathrm{F}}$ implies that common developments across countries are responsible for most of the co-movement. In contrast, $S_{t}^{\varepsilon}$ shows a lower volatility of idiosyncratic components with average values closer to 0 , and no strong systematic relation with the overall measure. We observe similar patterns when looking at advanced economies and EMDEs separately, but the average level of synchronization and its increase over time are higher in advanced economies. ${ }^{27}$ That is not surprising, given the stronger ties and shared trends among them.

\footnotetext{
25 The averages are calculated across all the country pairs in our sample for each year.

${ }^{26}$ The number of components is determined in accordance with the values of eigenvalues higher than 1.

${ }^{27}$ The results presented in Figure 4 are shown separately for advanced economies and EMDEs in Appendix A4.
} 
We formally test for convergence and a potential break in synchronization, similar to Meller and Metiu (2017). More particularly, we run a simple OLS regression of the synchronization measures on a time trend (with Newey-West standard errors):

$$
S_{i j, t}=\alpha+\beta_{t}+\varepsilon_{t}
$$

and test for structural breaks with unknown break dates, in accordance with Andrews (1993). In case of a structural break, we introduce a dummy variable with values 1 from that point onwards, and 0 before. Table 3 summarizes the results. As expected, the overall degree of synchronization has increased over time and is larger in advanced economies than in EMDEs. The former is confirmed by a positive and statistically significant time trend for the whole sample (column 1), in advanced economies (column 2) and in EMDEs (column 3). The latter is confirmed by a constant closer to zero in advanced economies compared to the EMDEs. Finally, while there is no structural break in advanced economies, a break in synchronization is identified in EMDEs in 2010. The interaction term of the dummy variable and the time trend suggests a slight slowdown in the convergence process after 2010.

Table 3 Convergence regressions

\begin{tabular}{lccc}
\hline \hline & $(1)$ & $(2)$ & $(3)$ \\
\hline Time trend & $0.00854^{* * *}$ & $0.00864^{* * *}$ & $0.00689^{*}$ \\
& $(0.00132)$ & $(0.00147)$ & $(0.00343)$ \\
Dummy variable & No & No & Yes \\
& & & since 2010 \\
Constant & $-0.749^{* * *}$ & $-0.592^{* * *}$ & $-0.841^{* * *}$ \\
& $(0.0292)$ & $(0.0329)$ & $(0.0503)$ \\
\hline Sample & Full & Advanced & EMDEs \\
Observations & 34 & 34 & 34 \\
\hline \hline Standard errors in parentheses & & \\
${ }^{*} p<0.10,{ }^{* *} p<0.05,{ }^{* * *} p<0.01$ & & \\
\end{tabular}

\section{b. Drivers of synchronization}

In the following, we analyze some key determinants of synchronization across countries. Stronger trade integration has been shown to be strongly related to greater co-movement of business cycles (Frankel and Rose 1998, Baxter and Kouparitsas 2005, Burstein et al. 2008, Levchenko and di Giovanni 2010, Clark and van Wincoop 2001). Contrary to the result for cyclical fluctuations, however, Blonigen, Piger, and Sly (2014) find that the co-movement of shocks to trend levels of real GDP is significantly weaker among countries that trade intensively with one another. We analyze the impact of more bilateral trade on the synchronization of equilibrium interest rates.

In addition, we analyze whether similar demographic and economic trends are associated with more synchronized equilibrium interest rates. Among all the potential determinants of equilibrium rates, demography has been identified as the main factor. ${ }^{28}$ Demographic transitions impact equilibrium rates through three channels: changing labor input, changing life expectancy, and a changing proportion of those dissaving (Brand et al. 2018). Lunsford and West (2017) confirm that demographics to play a dominant role in the Unites States and Fiorentini et al. (2018) confirm the crucial role of demographics for a set of other advanced economies. We test whether a greater similarity of demographic trends

\footnotetext{
${ }^{28}$ Examples include Krueger and Ludwig (2007), Carvalho et al. (2016), Favero et al. (2016), Gagnon et al. (2016), Kara and von Thadden (2016), Ferrero et al. (2019), Aksoy et al. (2019), and Del Negro et al. (2019).
} 
translates into a larger co-movement of equilibrium interest rates. In line with the secular stagnation hypothesis, declining trend growth has been argued to be behind the decline in real interest rates (Garnier and Wilhelmsen 2009, Fries et al. 2016). However, Hamilton et al. (2016) and Wynne and Zhang (2018) only find a modest relationship between equilibrium rates and potential output growth. We test whether a higher correlation of GDP growth rates has an impact on how synchronized equilibrium rates are. Finally, co-movements in inflation rates include information about the importance of common shocks and the similarity of central bank reaction functions (Neely and Rapach 2011) and may impact long-run dynamics. We hence also check whether higher bilateral correlations of inflation rates affect the synchronization of equilibrium rates.

In other words, we regress average bilateral synchronizations on pairwise correlation coefficients of the dependency ratio, ${ }^{29} \mathrm{GDP}$ growth, and inflation, as well as on bilateral trade flows:

$$
S_{i j}=\alpha+\beta \rho_{i j}^{\Delta \text { dep.ratio }}+\gamma \rho_{i j}^{\Delta g d p}+\theta \rho_{i j}^{i n f}+\vartheta \text { trade }_{i j}+\varepsilon_{i j},
$$

where $\rho_{i j}^{x}$ stands for the pairwise correlation coefficients of the dependency ratio, GDP growth, and inflation, and $t r a d e_{i j}$ stands for bilateral trade linkages. The estimation period is from 1996 to $2019 .{ }^{30}$

Table 4 Determinants of synchronization

\begin{tabular}{lccccc}
\hline \hline & $(1)$ & $(2)$ & $(3)$ & $(4)$ & $(5)$ \\
\hline Dependency ratio corr & $0.0605^{* * *}$ & $0.0625^{* * *}$ & $0.0609^{* * *}$ & 0.0125 & $0.0851^{* *}$ \\
& $(0.0175)$ & $(0.0169)$ & $(0.0167)$ & $(0.0193)$ & $(0.0404)$ \\
GDP growth corr & $0.196^{* * *}$ & $0.125^{* * *}$ & $0.0915^{* * *}$ & $0.173^{* * *}$ & 0.0354 \\
& $(0.0264)$ & $(0.0268)$ & $(0.0280)$ & $(0.0503)$ & $(0.0806)$ \\
Inflation corr & & & & & \\
& & $0.254^{* * *}$ & $0.244^{* * *}$ & -0.00497 & $0.431^{* * *}$ \\
Bilateral trade & $(0.0306)$ & $(0.0304)$ & $(0.0352)$ & $(0.0694)$ \\
& & & $0.0526^{* * *}$ & $0.0404^{* * *}$ & 0.138 \\
Constant & & $(0.0137)$ & $(0.0122)$ & $(0.131)$ \\
& $-0.594^{* * *}$ & $-0.635^{* * *}$ & $-0.636^{* * *}$ & $-0.509^{* * *}$ & $-0.753^{* * *}$ \\
& $(0.0110)$ & $(0.0116)$ & $(0.0116)$ & $(0.0289)$ & $(0.0232)$ \\
\hline Sample & Full & Full & Full & Advanced & EMDEs \\
Observations & 861 & 861 & 861 & 210 & 210 \\
\hline \hline Standard errors in parentheses & & & & \\
${ }^{*} p<0.10,{ }^{* *} p<0.05,{ }^{* * *} p<0.01$ & & & &
\end{tabular}

The results are reported in Table 4. Higher bilateral correlations between dependency ratios and between GDP growth rates are both statistically significantly (at the 1 percent level) associated with stronger synchronizations of equilibrium interest rates (column 1). The same is true for a stronger co-movement of inflation rates (column 2) and bilateral trade (column 3). Even when including all these determinants jointly, they all remain significant at the 1 percent level. However, there seem to be some crucial differences between advanced economies and EMDEs. In the former, demographic trends and inflation dynamics are not statistically significant and instead only economic trends and trade matter. One reason could be that there is limited variation in the other variables across advanced economies, so that the

\footnotetext{
${ }^{29}$ The age dependency ratio is defined as the ratio of younger dependents (people younger than 15 years) to the working-age population (those ages 15-64 years). Before computing correlation coefficients, we take first differences. Other data series related to the age composition give very similar results.

${ }^{30}$ Bilateral trade data are not available before that.
} 
impact cannot be identified. For the latter, on the other hand, GDP growth and bilateral trade are not significant and instead demographic trends and inflation dynamics are crucial. The important role of inflation dynamics could be related to cycles in commodity prices.

\section{Discussion}

We propose a methodology suitable to estimate equilibrium interest rates for a large set of countries, including those with only annual data and large fluctuations of real interest rates, and provide estimates for 50 countries. From these, we construct a global equilibrium interest rate, compare the rates across advanced economies and EMDEs, and analyze synchronization of equilibrium interest rates across countries.

Our analysis yields the following key results: the global equilibrium rate was above 3 percent in the 1980s, declined slowly subsequently down to 2 percent in 2000, dropped strongly between 2000 and 2003 and further between 2009 and 2012 when it fell below zero, and has recovered only minimally since then. In 2019, it stood at -0.5 percent. Equilibrium interest rates in EMDEs exhibit some peculiarities. Their rates were lower than those of advanced economies in the 1970s and started to surge later; they did not increase as much in the 1980s but declined much slower subsequently; and while they also declined during the global financial crisis, as they went below zero only briefly and started recovering faster and stronger than those in advanced economies. While the equilibrium rate of advanced economies was negative in 2019, it stood at 0.5 percent in EMDEs. In line with economic integration and rising global capital markets, synchronization of equilibrium rates increased over time and is larger among advanced economies. Equilibrium rates of countries with stronger trade linkages and more similar trends in demographics and GDP growth are more synchronized.

With the COVID-19 pandemic, the future path of equilibrium interest rates is uncertain. Our procedure will allow tracking equilibrium interest rates not only in advanced economies, but in EMDEs as well. The future dynamics of equilibrium interest rates have major policy implications. For example, lower equilibrium interest rates strengthen the argument for large public investment and work programs. In addition, fiscal policy may become more important to stabilize business cycles (DeLong and Summers 2012, Eggertsson and Mehrotra 2014). Finally, low rates encourage risk taking in financial markets and hence macro- and micro-prudential policy is likely to become an increasingly important tool to help safeguard financial stability (Rachel and Smith 2015). The increasing synchronization of equilibrium rates documented above suggests potential for greater macroprudential policy coordination in the future. In light of the recent divergence of equilibrium rates in advanced economies and EMDEs, some of the latter may reexamine their extensive capital controls.

While we made no attempt to use our estimates to refine the explanations of the recent decline in equilibrium interest rates, they certainly lend themselves to such an analysis. ${ }^{31}$ Among others, such analyses could refine our understanding of the role of excess global savings, within-country inequality, public investment, labor force participation, human capital, and political institutions in determining equilibrium interest rates. And deeper insights into the drivers will in turn allow improving our understanding of likely future developments in advanced economies and EMDEs and whether the recent divergence will continue.

\footnotetext{
${ }^{31}$ We make our estimates publicly available, of course.
} 


\section{Bibliography}

Aksoy, Y., Basso, H.S., Smith, R.P. and Grasl, T., 2019. Demographic structure and macroeconomictrends. American Economic Journal: Macroeconomics, 11(1), pp.193-222.

Andrews, D.W., 1993. Tests for parameter instability and structural change with unknown change point. Econometrica: Journal of the Econometric Society, pp.821-856.

Baxter, M. and Kouparitsas, M.A., 2005. Determinants of business cycle co-movement: a robust analysis. Journal of Monetary Economics, 52(1), pp.113-157.

Belke, A. and Klose, J., 2017. Equilibrium real interest rates and secular stagnation: An empirical analysis for euro area member countries. JCMS: Journal of Common Market Studies, 55(6), pp.1221-1238.

Beyer, R.C. and Wieland, V., 2019. Instability, imprecision and inconsistent use of equilibrium real interest rate estimates. Journal of International Money and Finance, 94, pp.1-14.

Blake, A. and Mumtaz, H., 2015. Applied Bayesian econometrics for central bankers. Handbooks.

Blinder, A.S., 1999. Central banking in theory and practice. Mit press.

Blonigen, B.A., Piger, J. and Sly, N., 2014. Comovement in GDP trends and cycles among trading partners. Journal of International Economics, 94(2), pp.239-247.

Brand, C., Bielecki, M. and Penalver, A., 2018. The natural rate of interest: estimates, drivers, and challenges to monetary policy. ECB Occasional Paper, (217).

Burstein, A., Kurz, C. and Tesar, L., 2008. Trade, production sharing, and the international transmission of business cycles. Journal of Monetary Economics, 55(4), pp.775-795.

Canova, F., 2011. Methods for applied macroeconomic research. Princeton University Press.

Carter, C.K. and Kohn, R., 1994. On Gibbs sampling for state space models. Biometrika, 81(3), pp.541553.

Carvalho, C., Ferrero, A. and Nechio, F., 2016. Demographics and real interest rates: Inspecting the mechanism. European Economic Review, 88, pp.208-226.

Cesa-Bianchi, A., Imbs, J. and Saleheen, J., 2019. Finance and synchronization. Journal of International Economics, 116, pp.74-87.

Chan, J.C. and Grant, A.L., 2016. Modeling energy price dynamics: GARCH versus stochastic volatility. Energy Economics, 54, pp.182-189.

Christensen, J.H. and Rudebusch, G.D., 2017. New evidence for a lower new normal in interest rates. FRBSF Economic Letter, 17.

Clark, T.E. and Kozicki, S., 2005. Estimating equilibrium real interest rates in real time. The North American Journal of Economics and Finance, 16(3), pp.395-413.

Clark, T.E. and Van Wincoop, E., 2001. Borders and business cycles. Journal of International Economics, 55(1), pp.59-85.

Corsetti, G., Pericoli, M. and Sbracia, M., 2005. 'Some contagion, some interdependence': More pitfalls in tests of financial contagion. Journal of International Money and Finance, 24(8), pp.11771199.

Cukierman, A., 2016. Reflections on the natural rate of interest, its measurement, monetary policy and the zero lower bound.

Dahlquist, M. and Hasseltoft, H., 2013. International bond risk premia. Journal of International Economics, 90(1), pp.17-32.

Danielsson, J., 1994. Stochastic volatility in asset prices estimation with simulated maximum likelihood. Journal of Econometrics, 64(1-2), pp.375-400. 
Del Negro, M., Giannone, D., Giannoni, M.P. and Tambalotti, A., 2017. Safety, liquidity, and the natural rate of interest. Brookings Papers on Economic Activity, 2017(1), pp.235-316.

Del Negro, M., Giannone, D., Giannoni, M.P. and Tambalotti, A., 2019. Global trends in interest rates. Journal of International Economics, 118, pp.248-262.

DeLong, J.B., Summers, L.H., Feldstein, M. and Ramey, V.A., 2012. Fiscal policy in a depressed economy [with comments and discussion]. Brookings Papers on Economic Activity, pp.233297.

Di Giovanni, J. and Levchenko, A.A., 2010. Putting the parts together: trade, vertical linkages, and business cycle co-movement. American Economic Journal: Macroeconomics, 2(2), pp.95-124.

Eggertsson, G.B. and Mehrotra, N.R., 2014. A model of secular stagnation (No. w20574). National Bureau of Economic Research.

Favero, C.A., Gozluklu, A.E. and Yang, H., 2016. Demographics and the behavior of interest rates. IMF Economic Review, 64(4), pp.732-776.

Ferrero, G., Gross, M. and Neri, S., 2019. On secular stagnation and low interest rates: demography matters. International Finance, 22(3), pp.262-278.

Fiorentini, G., Galesi, A., Pérez-Quirós, G. and Sentana, E., 2018. The rise and fall of the natural interest rate.

Forbes, K.J. and Rigobon, R., 2002. No contagion, only interdependence: measuring stock market comovements. The Journal of Finance, 57(5), pp.2223-2261.

Frankel, J.A. and Rose, A.K., 1998. The endogeneity of the optimum currency area criteria. The Economic Journal, 108(449), pp.1009-1025.

Fries, S., Mésonnier, J.S., Mouabbi, S. and Renne, J.P., 2016. National natural rates of interest and the single monetary policy in the Euro Area. Banque de France (No. 611). Working Paper Series.

Fujita, S. and Fujiwara, I., 2016. Declining trends in the real interest rate and inflation: The role of aging.

Gagnon, E., Johannsen, B.K. and Lopez-Salido, D., 2016. Understanding the New Normal: the role of demographics.

Garnier, J. and Wilhelmsen, B.R., 2009. The natural rate of interest and the output gap in the euro area: a joint estimation. Empirical Economics, 36(2), pp.297-319.

Giannone, D., Lenza, M. and Reichlin, L., 2008. Business cycles in the euro area (No. w14529). National Bureau of Economic Research.

Gourinchas, P.O. and Rey, H., 2019. Global real rates: A secular approach.

Goy, G., \& van den End, J. W. (2020). The Impact of the COVID-19 crisis on the Equilibrium Interest Rate. VoxEU. https://voxeu.org/article/impact-covid-19-crisis-equilibrium-interest-rate.

Grassi, S. and Proietti, T., 2008. Has the Volatility of US Inflation Changed and How? MPRA Paper 11453, University Library of Munich, Germany.

Hamilton, J.D., Harris, E.S., Hatzius, J. and West, K.D., 2016. The equilibrium real funds rate: Past, present, and future. IMF Economic Review, 64(4), pp.660-707.

Hledik, T. and Vlček, J., 2018. Quantifying the Natural Rate of Interest in a Small Open Economy-The Czech Case. Czech National Bank.

Holston, K., Laubach, T. and Williams, J.C., 2017. Measuring the natural rate of interest: International trends and determinants. Journal of International Economics, 108, pp.S59-S75.

Hsieh, D.A., 1991. Chaos and nonlinear dynamics: application to financial markets. The Journal of Finance, 46(5), pp.1839-1877. 
Jacquier, E., Polson, N.G. and Rossi, P.E., 2004. Bayesian analysis of stochastic volatility models with fat-tails and correlated errors. Journal of Econometrics, 122(1), pp.185-212.

Jacquier, P. and Polson, N., 1994. Rossi,". J. Business and Economics Statistics, 124.

Johannsen, B.K. and Mertens, E., 2016. The expected real interest rate in the long run: Time series evidence with the effective lower bound (No. 2016-02-09). Board of Governors of the Federal Reserve System (US).

Jordà, Ò., Schularick, M., Taylor, A.M. and Ward, F., 2017. Global financial cycles and risk premia. NBER Working Paper, 24677.

Jordà, Ò., Singh, S. R., and Taylor, A.M.,2020. Longer-run economic consequences of pandemics. NBER Working Paper, 26934.

Jotikasthira, C., Le, A. and Lundblad, C., 2015. Why do term structures in different currencies comove?. Journal of Financial Economics, 115(1), pp.58-83.

Juselius, M., Borio, C.E., Disyatat, P. and Drehmann, M., 2016. Monetary policy, the financial cycle and ultralow interest rates. Bank of Finland Research Discussion Paper, (24).

Kalemli-Ozcan, S., Papaioannou, E. and Peydró, J.L., 2013. Financial regulation, financial globalization, and the synchronization of economic activity. The Journal of Finance, 68(3), pp.1179-1228.

Kara, E. and von Thadden, L., 2016. Interest rate effects of demographic changes in a New Keynesian life-cycle framework. Macroeconomic Dynamics, 20(1), pp.120-164.

Kiley, M.T., 2015. What can the data tell us about the equilibrium real interest rate?. Available at SSRN 2665710.

Kim, S., Shephard, N. and Chib, S., 1998. Stochastic volatility: likelihood inference and comparison with ARCH models. The Review of Economic Studies, 65(3), pp.361-393.

King, M. and Low, D., 2014. Measuring the "world" real interest rate (No. w19887). National Bureau of Economic Research.

Klose, J., 2020. Equilibrium real interest rates for the BRICS countries. The Journal of Economic Asymmetries, 21, p.e00155.

Krueger, D. and Ludwig, A., 2007. On the consequences of demographic change for rates of returns to capital, and the distribution of wealth and welfare. Journal of Monetary Economics, 54(1), pp.49-87.

Krustev, G., 2019. The natural rate of interest and the financial cycle. Journal of Economic Behavior \& Organization, 162, pp.193-210.

Kulish, M. and Rees, D., 2011. The yield curve in a small open economy. Journal of International Economics, 85(2), pp.268-279.

Laubach, T. and Williams, J.C., 2003. Measuring the natural rate of interest. Review of Economics and Statistics, 85(4), pp.1063-1070.

Laubach, T. and Williams, J.C., 2016. Measuring the natural rate of interest redux. Business Economics, 51(2), pp.57-67.

Levrero, E., 2019. Estimates of the natural rate of interest and the stance of monetary policies: a critical assessment. Institute for New Economic Thinking Working Paper Series, (88).

Lewis, K.F. and Vazquez-Grande, F., 2017. Measuring the natural rate of interest: Alternative specifications. Finance and Economics Discussion Series, 59.

Li, M. and Koopman, S.J., 2018. Unobserved components with stochastic volatility in us inflation: Estimation and signal extraction. 
Lubik, T.A. and Matthes, C., 2015. Calculating the natural rate of interest: A comparison of two alternative approaches. Richmond Fed Economic Brief, (Oct), pp.1-6.

Lunsford, K.G. and West, K.D., 2019. Some evidence on secular drivers of US safe real rates. American Economic Journal: Macroeconomics, 11(4), pp.113-39.

Mariano, R.S. and Murasawa, Y., 2003. A new coincident index of business cycles based on monthly and quarterly series. Journal of Applied Econometrics, 18(4), pp.427-443.

Meller, B. and Metiu, N., 2017. The synchronization of credit cycles. Journal of Banking \& Finance, 82, pp.98-111.

Mendes, R.R., 2014. The neutral rate of interest in Canada (No. 2014-5). Bank of Canada Discussion Paper.

Morgan, D.P., Rime, B. and Strahan, P.E., 2004. Bank integration and state business cycles. The Quarterly Journal of Economics, 119(4), pp.1555-1584.

Moritz, S. and Bartz-Beielstein, T., 2017. imputeTS: time series missing value imputation in R. $R J$., 9(1), p.207.

Morley, J.C., Nelson, C.R. and Zivot, E., 2003. Why are the Beveridge-Nelson and unobservedcomponents decompositions of GDP so different?. Review of Economics and Statistics, 85(2), pp.235-243.

Neely, C.J. and Rapach, D.E., 2011. International comovements in inflation rates and country characteristics. Journal of International Money and Finance, 30(7), pp.1471-1490.

Potjagailo, G. and Wolters, M., 2020. Global financial cycles since 1880.

Probst, J., 2019. Global real interest rate dynamics from the late 19th century to today. International Review of Economics \& Finance, 59, pp.522-547.

Rachel, L. and Smith, T., 2015. Secular drivers of the global real interest rate.

Schmelzing, Paul. 2020. Eight centuries of global real interest rates, $r-\mathrm{g}$, and the 'suprasecular' decline, 1311-2018. Bank of England Staff Working Paper 845

Stock, J.H. and Watson, M.W., 2007. Why has US inflation become harder to forecast?. Journal of Money, Credit and banking, 39, pp.3-33.

Summers, L.H., 2014. US economic prospects: Secular stagnation, hysteresis, and the zero lower bound. Business Economics, 49(2), pp.65-73.

Swanson, E.T. and Williams, J.C., 2014. Measuring the effect of the zero lower bound on yields and exchange rates in the UK and Germany. Journal of International Economics, 92, pp.S2-S21.

Taylor, J.B. and Wieland, V., 2016. Finding the equilibrium real interest rate in a fog of policy deviations. Business Economics, 51(3), pp.147-154.

Wieland, V., 2018. R-star: The Natural Rate and its Role in Monetary Policy. The Structural Foundations Of Monetary Policy.

Wicksell, K., 1936. Interest and prices. Ludwig von Mises Institute.

Woodford, M., 2003. Interest and prices: Foundations of a theory of monetary policy. Princeton University Press.

Wright, J.H., 2011. Term premia and inflation uncertainty: Empirical evidence from an international panel dataset. American Economic Review, 101(4), pp.1514-34.

Wynne, M.A. and Zhang, R., 2018. Measuring the world natural rate of interest. Economic Inquiry, 56(1), pp.530-54. 
Appendix

A1 Data coverage and sources by country

\begin{tabular}{|c|c|c|c|}
\hline Country & Period & Data Source & Outliers \\
\hline Austria & 1970-2019 & OECD CPI and IFS MMR extended by OECD & \\
\hline Australia & $1970-2019$ & JST extended by IMF WEO CPI and IFS MMR & \\
\hline Barbados & $1977-2019$ & IMF WEO CPI and IFS discount rate/treasury bill & \\
\hline Bangladesh & $1971-2019$ & WB WDI deflator and IFS policy rate & 4 \\
\hline Belgium & $1870-2019$ & $\begin{array}{l}\text { JST extended by IMF WEO CPI and Belgostat money market rates - } \\
\text { reference rate of treasury certificates }\end{array}$ & \\
\hline Belize & $1977-2019$ & WB WDI deflator inflation and IFS policy rate & 2 \\
\hline Botswana & $1976-2019$ & WB WDI CPI and IFS discount rate & \\
\hline Burundi & $1977-2019$ & WB WDI CPI and IFS discount rate (till 2016) & 1 \\
\hline Canada & $1934-2019$ & JST extended by IMF WEO CPI and BoC treasury bill rate & \\
\hline China & 1990-2019 & WB WDI CPI and IFS discount rate & \\
\hline Colombia & $1970-2019$ & WB WDI CPI and IFS discount rate & 2 \\
\hline Denmark & $1870-2019$ & JST extended by IMF WEO CPI and IFS money market rate & \\
\hline $\begin{array}{l}\text { Egypt, Arab } \\
\text { Rep. }\end{array}$ & $1970-2019$ & WB WDI deflator inflation and IFS discount rate & \\
\hline Finland & $1870-2019$ & JST extended by IMF WEO CPI and FRED 3-month interbank rate & \\
\hline France & $1870-2017$ & $\begin{array}{l}\text { JST extended by WB WDI CPI and IFS treasury bill rate; } \\
\text { WB WDI CPI and FRED interbank rate (1970-2018) }\end{array}$ & \\
\hline $\begin{array}{l}\text { Gambia, } \\
\text { The }\end{array}$ & $1981-2019$ & WB WDI CPI and IFS policy rate & 1 \\
\hline Germany & $1870-2019$ & JST extended by IFS CPI and Bundesbank EONIA monthly average & \\
\hline Greece & $1980-2019$ & WB WDI CPI and FRED interbank rate & \\
\hline Guyana & $1970-2019$ & WB WDI deflator inflation and IFS policy rate & 6 \\
\hline Hungary & 1983-2019 & WB WDI CPI and FRED immediate CB rate & \\
\hline India & 1970-2019 & WB WDI CPI and IFS discount rate & \\
\hline Indonesia & $1983-2018$ & WB WDI CPI and IFS money market rate (2018) & 1 \\
\hline Ireland & $1972-2018$ & WB WDI CPI and IFS money market rate (2018) & \\
\hline Italy & $1870-2019$ & WB IMF WEO and IFS treasury bill rate & \\
\hline Japan & $1870-2019$ & WB IMF WEO and IFS money market rate & \\
\hline Jordan & $1970-2019$ & WB WDI CPI and IFS discount rate & \\
\hline Korea, Rep. & 1970-2019 & WB WDI CPI and IFS discount rate & \\
\hline Kuwait & $1975-2019$ & WB and IMF WEO and IFS discount rate & \\
\hline Lesotho & $1980-2019$ & WB WDI CPI and IFS discount rate & 2 \\
\hline Malaysia & $1971-2019$ & WB WDI CPI and IFS money market rate & \\
\hline Mauritania & $1970-2019$ & WB WDI deflator inflation and IFS discount rate & 1 \\
\hline Mauritius & $1979-2019$ & WB WDI CPI and IFS money market rate & 1 \\
\hline Mexico & 1981-2019 & WB WDI CPI and IFS money market rate & 4 \\
\hline Morocco & $1970-2019$ & WB WDI CPI and IFS discount rate & 2 \\
\hline Netherlands & $1870-2019$ & JST extended by IMF WEO CPI and OECD short-term interest rate & \\
\hline Norway & $1870-2019$ & JST extended by Norges Bank CPI and NB marginal liquidity rate & \\
\hline $\begin{array}{l}\text { New } \\
\text { Zealand }\end{array}$ & $1974-2019$ & WB WDI CPI and OECD short-term interest rate & \\
\hline Oman & $1980-2018$ & IMF WEO CPI and IFS discount rate & \\
\hline Pakistan & $1970-2019$ & WB WDI CPI and IFS money market rate & \\
\hline Philippines & $1977-2019$ & WB WDI CPI and IFS money market rate & 1 \\
\hline
\end{tabular}




\begin{tabular}{|l|l|l|c|}
\hline Portugal & $1879-2019$ & JST extended by IMF WEO CPI and FRED 3-month interbank rate & 1 \\
\hline Singapore & $1972-2019$ & WB WDI CPI and IFS money market rate & \\
\hline South Africa & $1976-2019$ & WB WDI CPI and IFS money market rate & \\
\hline Spain & $1870-2019$ & WB WDI CPI and IFS money market rate & \\
\hline Sweden & $1870-2019$ & JST extended by Statistics Sweden CPI and IFS treasury bill rate & \\
\hline Switzerland & $1870-2019$ & JST extended by IMF WEO CPI and IFS \& SNB money market rate & \\
\hline $\begin{array}{l}\text { Trinidad and } \\
\text { Tobago }\end{array}$ & $1970-2019$ & WB WDI CPI and IFS discount rate & \\
\hline Thailand & $1977-2019$ & WB WDI CPI and IFS discount rate & $\begin{array}{l}\text { JST extended by IMF WEO CPI and Measuring Worth, Short-Term } \\
\text { Rate: Ordinary Funds, Contemporary Series }\end{array}$ \\
\hline $\begin{array}{l}\text { United } \\
\text { Kingdom }\end{array}$ & $1870-2019$ & $\begin{array}{l}\text { JST extended by Bureau of Labor Statistics CPI and Measuring } \\
\text { Worth, Short-Term Rate: Surplus Funds, Contemporary Series }\end{array}$ & \\
\hline $\begin{array}{l}\text { United } \\
\text { States }\end{array}$ & $1870-2019$ &
\end{tabular}

Notes: CPI stands for consumer price index, MMR for money market rate, IFS stands for International Financial Statistics, WDI for World Development Indicators, WEO for World Economic Outlook, whereas JST stands for Jordà-Schularick-Taylor Macrohistory Database. An outlier is defined as a value of observed real interest rate higher than 20 percentage points in absolute terms.

Sources: International Monetary Fund, World Bank, OECD, Jordà-Schularick-Taylor Macrohistory Database, Fred St. Louis, Belgostat, Budnesbank, Norges Bank, US Bureau of Labor Statistics.

A2 Ex-ante real interest rates and equilibrium interest rates across countries

Australia

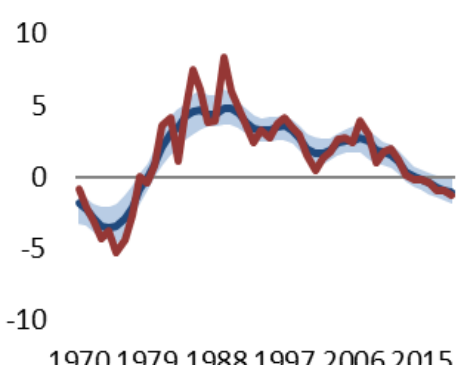

Barbados

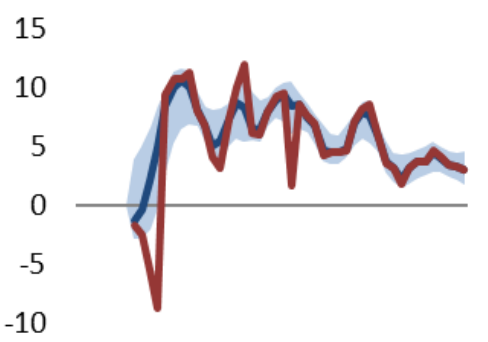

197019791988199720062015

Botswana

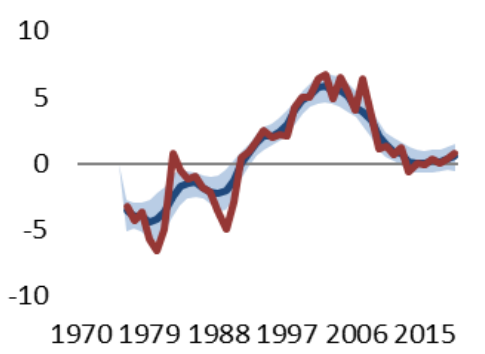

Austria

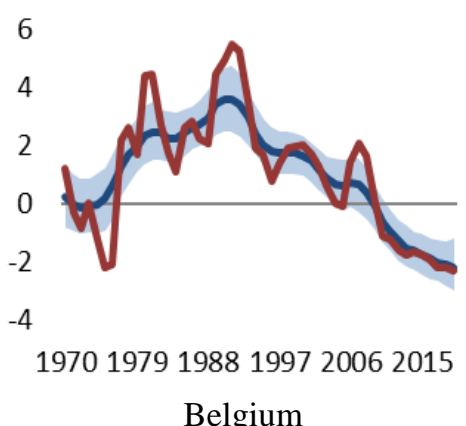

10

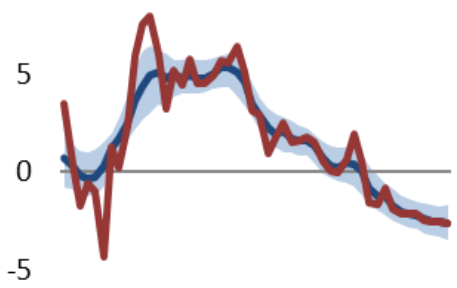

197019791988199720062015

Burundi

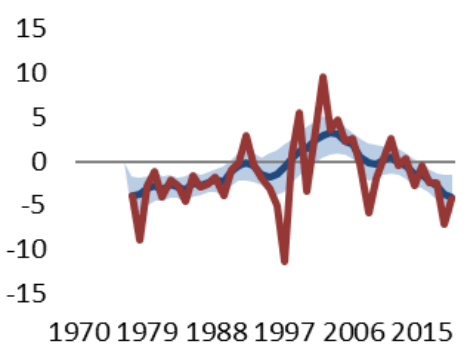

Bangladesh

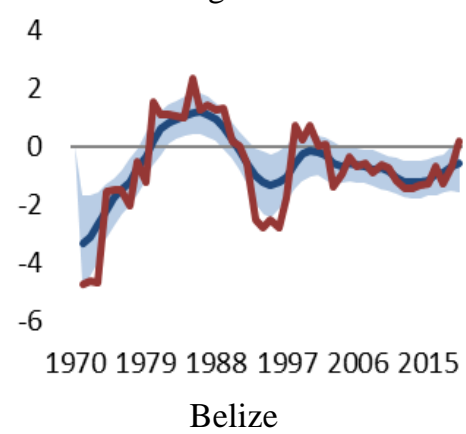

20

15

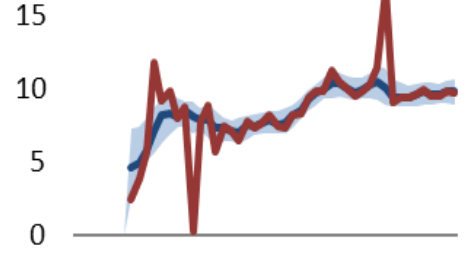

197019791988199720062015

Canada

10

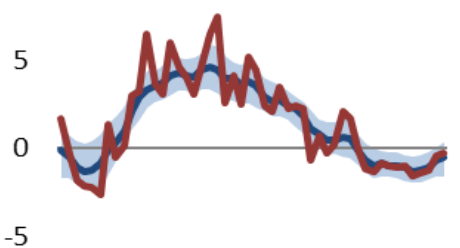

197019791988199720062015 
China

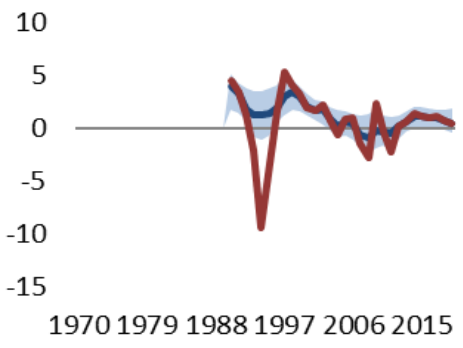

Egypt

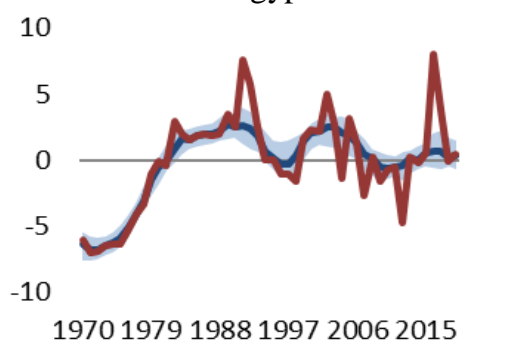

Gambia

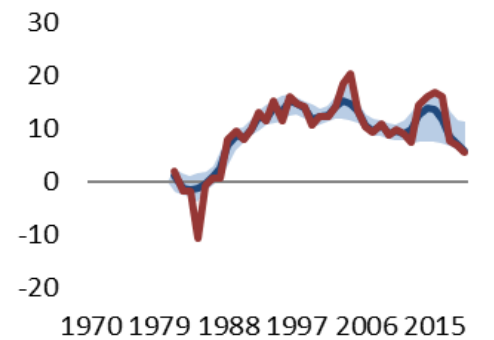

Guyana

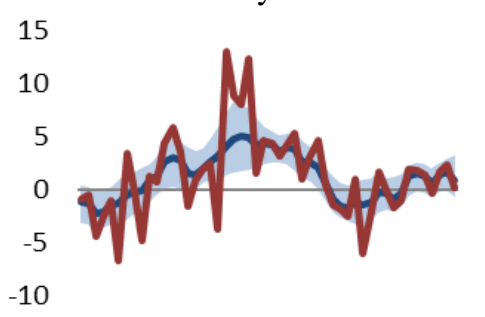

197019791988199720062015

Indonesia

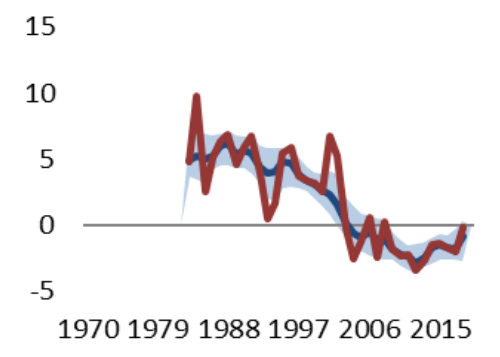

Japan
Colombia

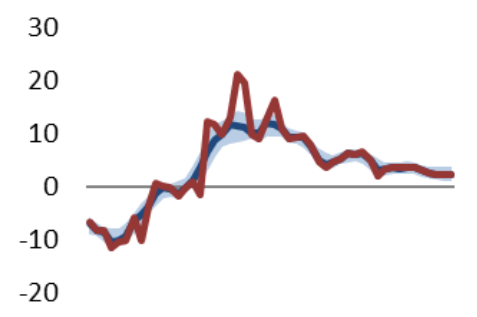

Finland

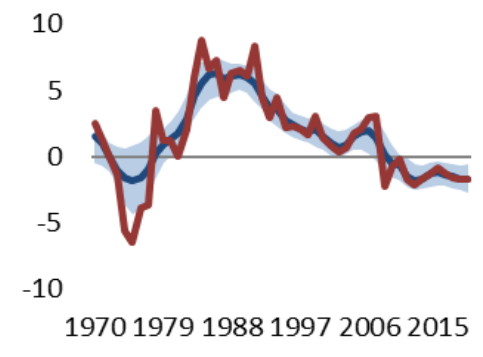

Germany

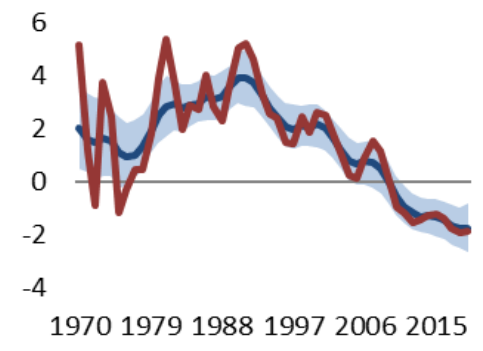

Hungary

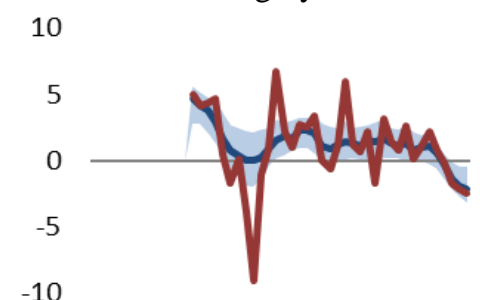

197019791988199720062015 Ireland

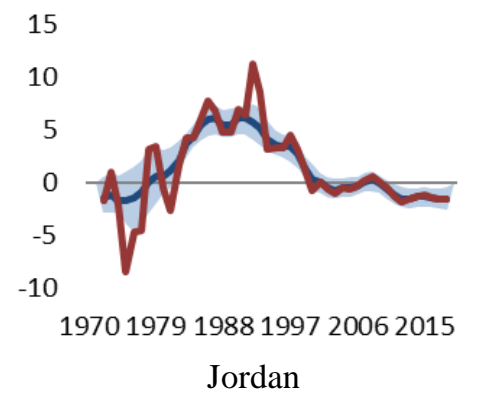

Denmark

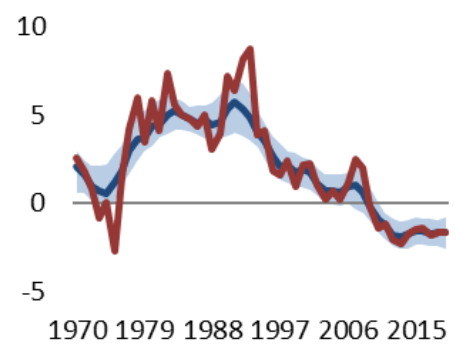

France

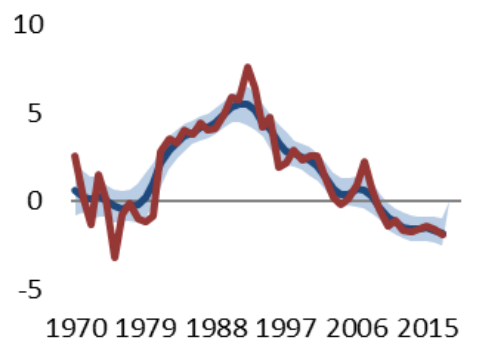

Greece

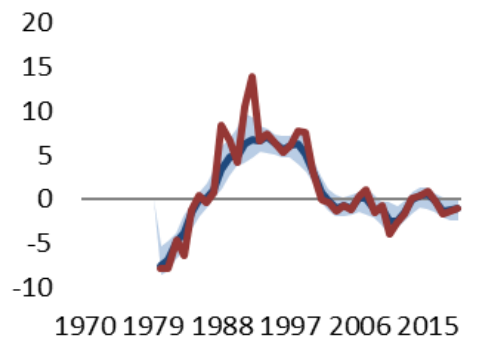
India

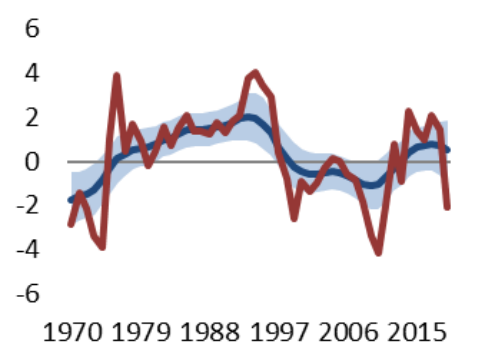
Italy

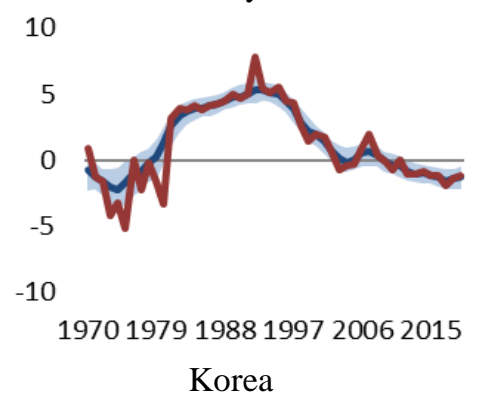




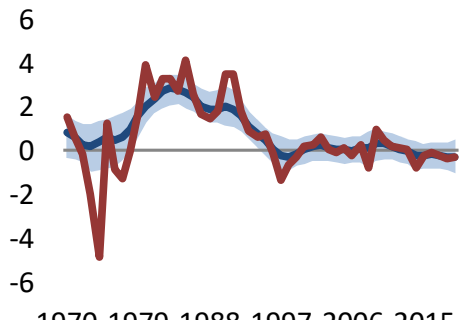

197019791988199720062015

Kuwait

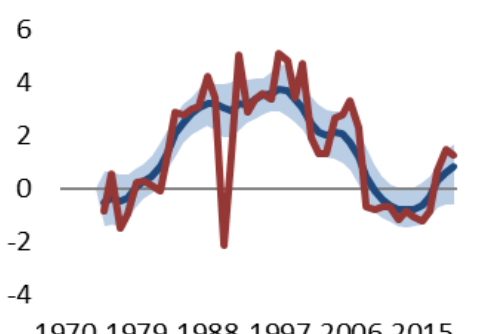

Mauritania

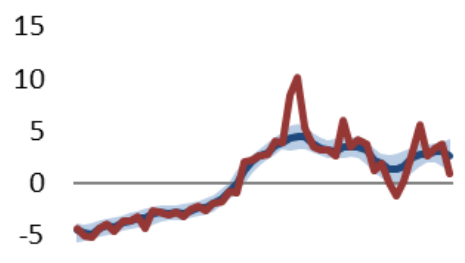

$-10$

197019791988199720062015

Morocco

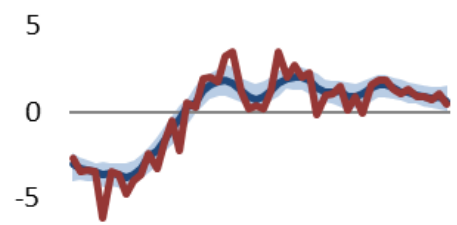

$-10$

197019791988199720062015

Norway

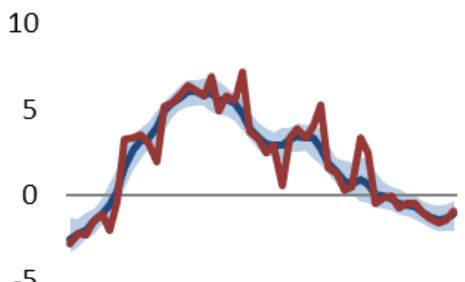

197019791988199720062015

Philippines

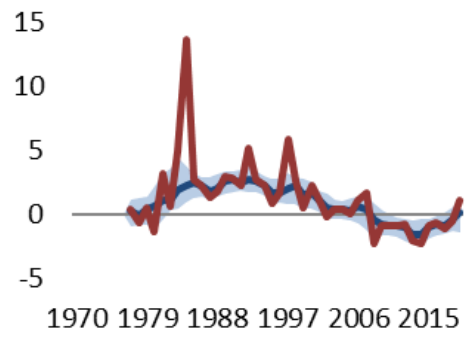

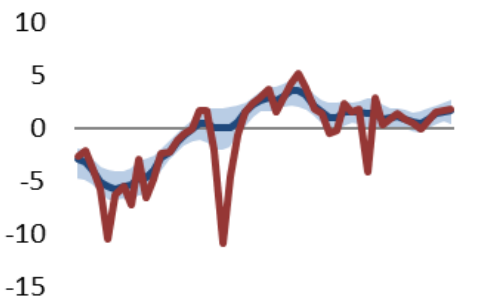

197019791988199720062015

Lesotho
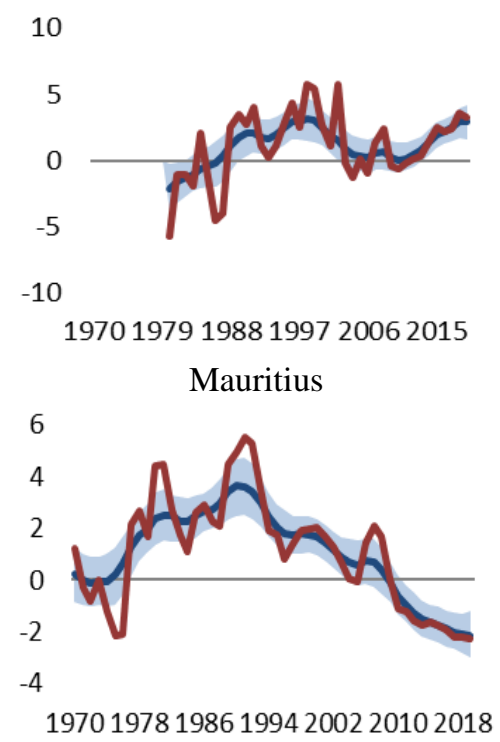

Netherlands

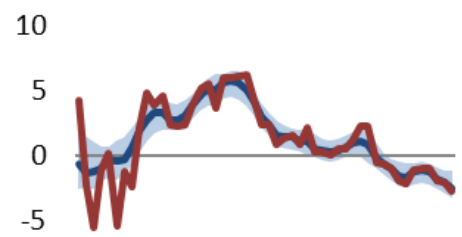

$-10$

197019791988199720062015

Oman

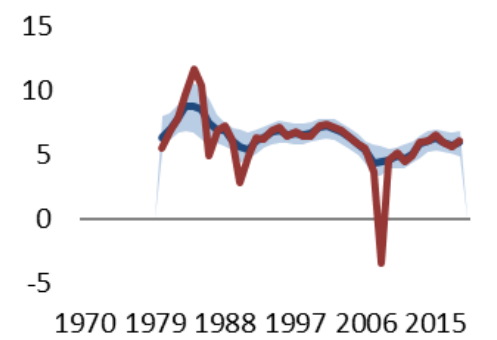

Portugal

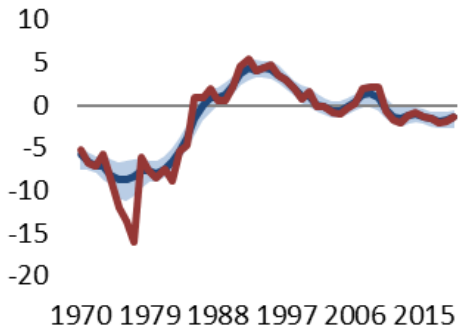

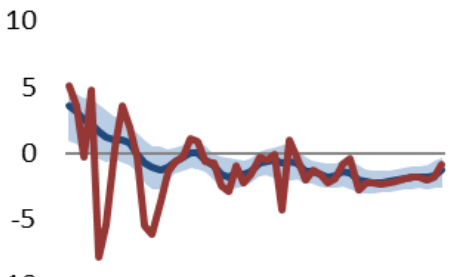

$-10$

197019791988199720062015

Malaysia

10

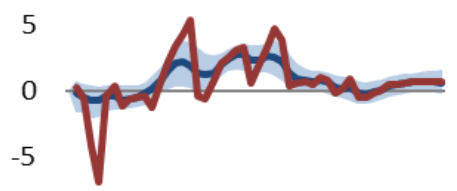

$-10$

197019791988199720062015

Mexico

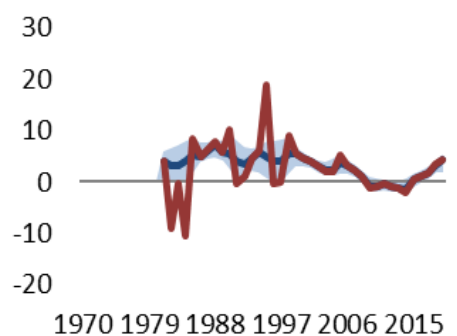

New Zealand

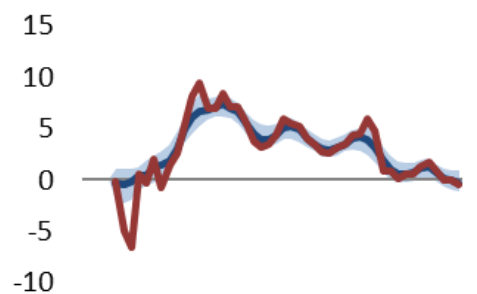

197019791988199720062015 Pakistan

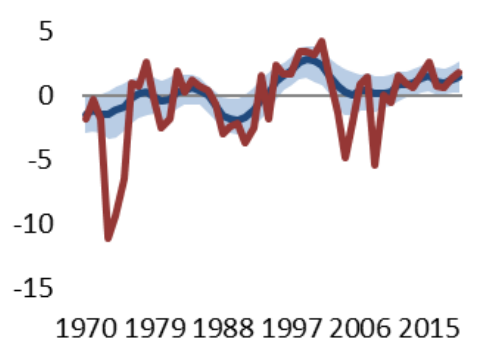

Singapore

10

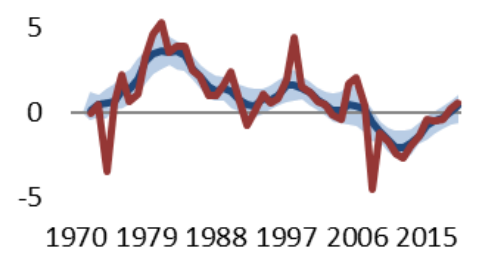



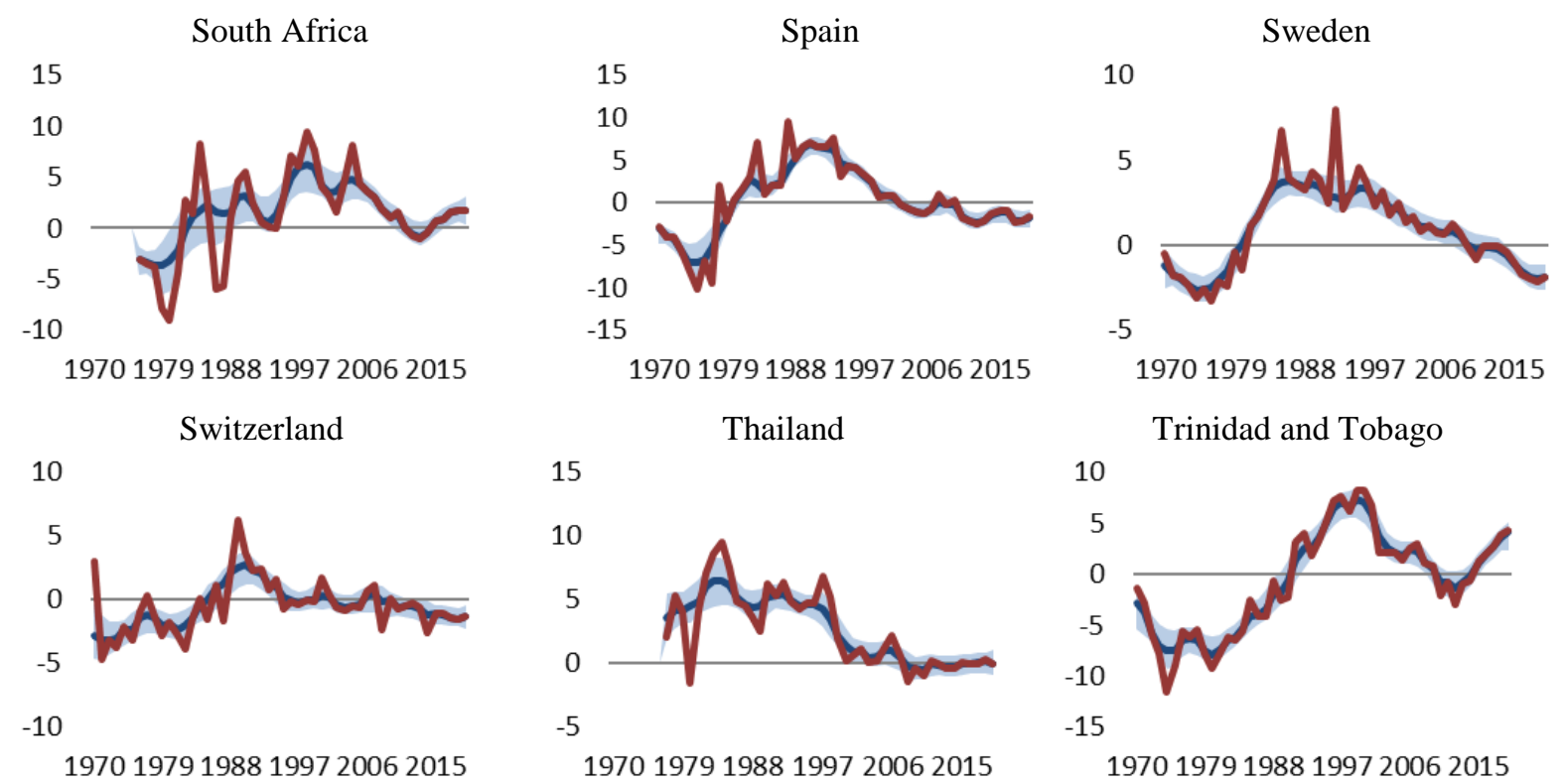

15

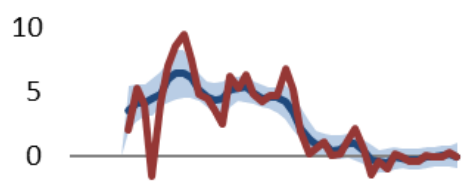

$-5$

197019791988199720062015

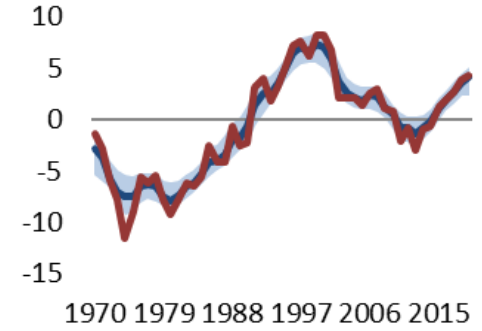

UK

USA
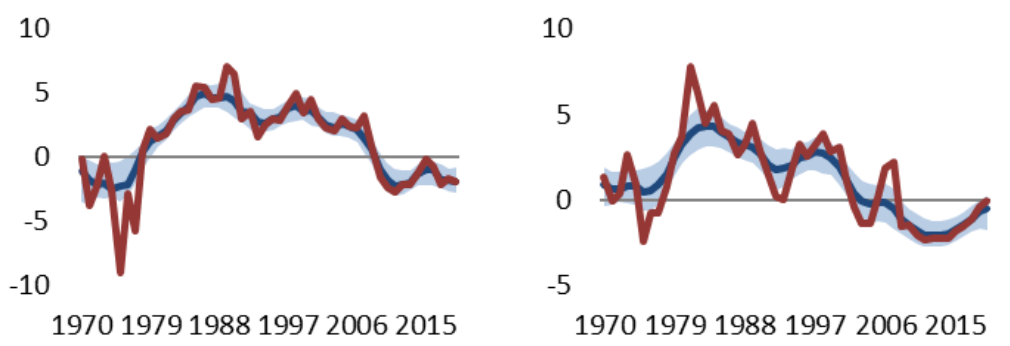

Note: The red lines show the ex-ante real interest rate, the blue line the equilibrium interest rate estimated with the benchmark model described in section 3. The light blue areas show the 90-percent credible intervals. 
A3 Time-varying volatility across advanced economies and EMDEs

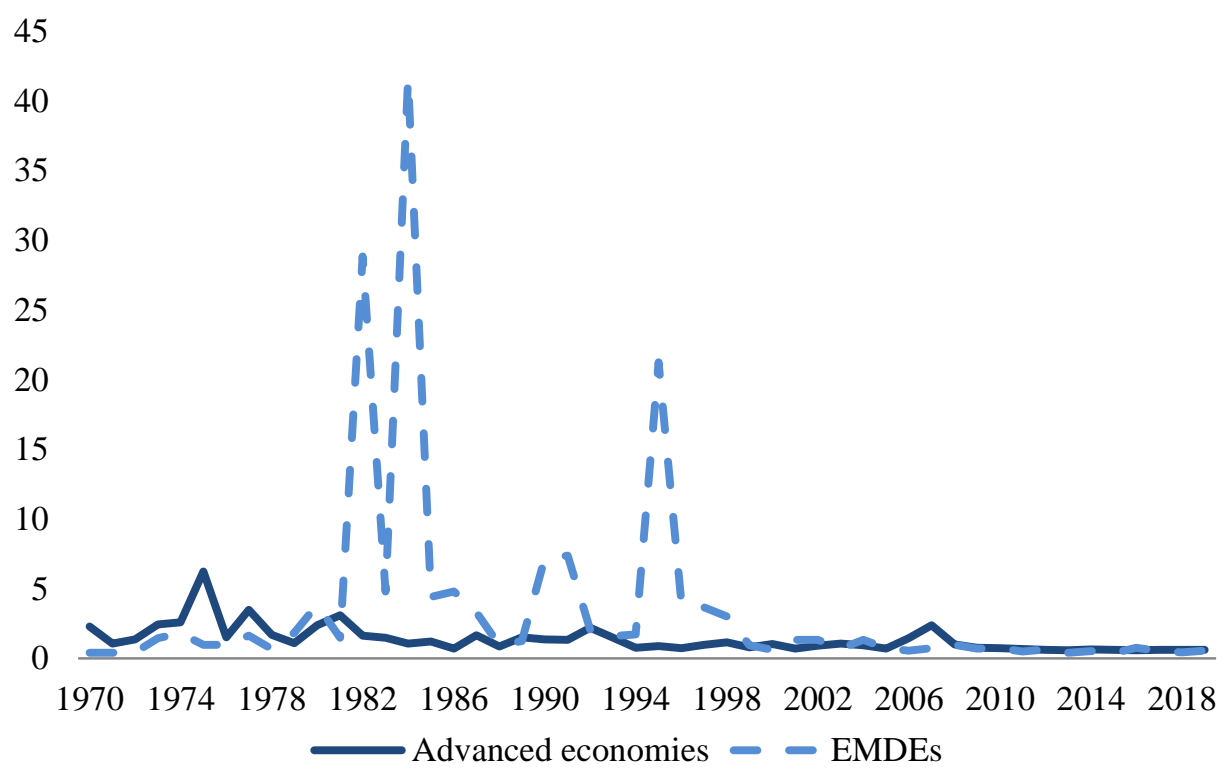

A4 Synchronization in advanced economies and EMDEs
A) Advanced economies
B) EMDEs

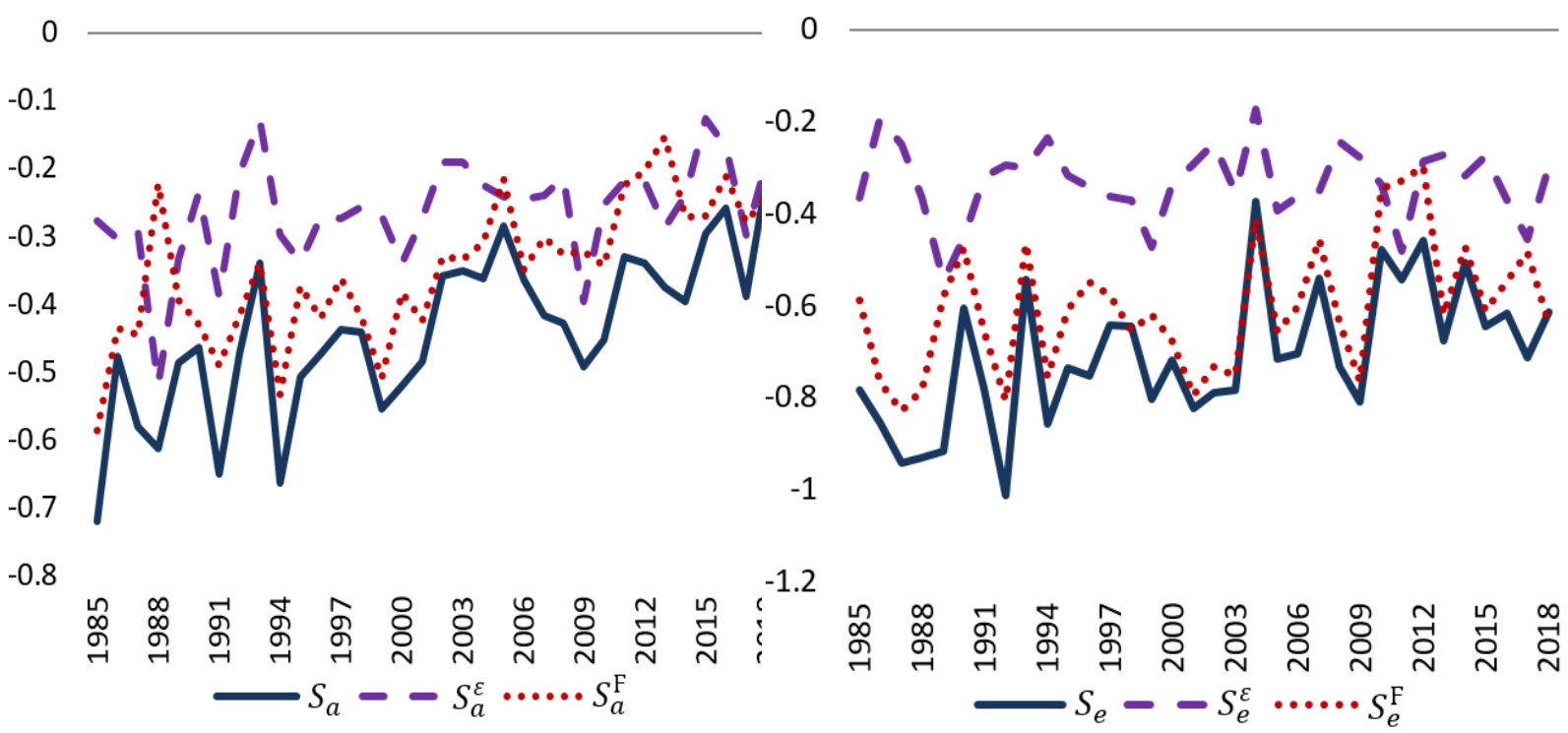

Note: The averages are calculated across respective (advanced or EMDEs) country pairs in our sample for each year. $F_{t}$ is proxied by the first 5 principal components in case of advanced economies, and first 8 principal components in EMDEs, on the full panel of $\Delta r_{i, t}^{*}$. 


\section{IMFS WORKING PAPER SERIES}

\section{Recent Issues}

\begin{tabular}{|c|c|c|}
\hline $145 / 2020$ & $\begin{array}{l}\text { Lars P. Feld } \\
\text { Volker Wieland }\end{array}$ & $\begin{array}{l}\text { The German Federal Constitutional Court } \\
\text { Ruling and the European Central Bank's } \\
\text { Strategy }\end{array}$ \\
\hline $144 / 2020$ & $\begin{array}{l}\text { Mátyás Farkas } \\
\text { Balint Tatar }\end{array}$ & $\begin{array}{l}\text { Bayesian Estimation of DSGE Models } \\
\text { with Hamiltonian Monte Carlo }\end{array}$ \\
\hline $143 / 2020$ & $\begin{array}{l}\text { Gregor Boehl } \\
\text { Felix Strobel }\end{array}$ & $\begin{array}{l}\text { U.S. Business Cycle Dynamics at the } \\
\text { Zero Lower Bound }\end{array}$ \\
\hline $142 / 2020$ & $\begin{array}{l}\text { Gregor Boehl } \\
\text { Gavin Goy } \\
\text { Felix Strobel }\end{array}$ & $\begin{array}{l}\text { A Structural Investigation of Quantitative } \\
\text { Easing }\end{array}$ \\
\hline $141 / 2020$ & Karl-Heinz Tödter & $\begin{array}{l}\text { Ein SIRD-Modell zur Infektionsdynamik } \\
\text { mit endogener Behandlungskapazität und } \\
\text { Lehren für Corona-Statistiken }\end{array}$ \\
\hline $140 / 2020$ & $\begin{array}{l}\text { Helmut Siekmann } \\
\text { Volker Wieland }\end{array}$ & $\begin{array}{l}\text { The Ruling of the Federal Constitutional } \\
\text { Court concerning the Public Sector } \\
\text { Purchase Program: A Practical Way } \\
\text { Forward }\end{array}$ \\
\hline $139 / 2020$ & Volker Wieland & $\begin{array}{l}\text { Verfahren zum Anleihekaufprogramm der } \\
\text { EZB }\end{array}$ \\
\hline $138 / 2020$ & $\begin{array}{l}\text { Francisco Gomes } \\
\text { Michael Haliassos } \\
\text { Tarun Ramadorai }\end{array}$ & Household Finance \\
\hline $137 / 2019$ & $\begin{array}{l}\text { Martin Kliem } \\
\text { Alexander Meyer-Gohde }\end{array}$ & $\begin{array}{l}\text { (Un)expected Monetary Policy Shocks } \\
\text { and Term Premia }\end{array}$ \\
\hline $136 / 2019$ & $\begin{array}{l}\text { Luc Arrondel } \\
\text { Hector Calvo-Pardo } \\
\text { Chryssi Giannitsarou } \\
\text { Michael Haliassos }\end{array}$ & Informative Social Interactions \\
\hline $135 / 2019$ & $\begin{array}{l}\text { Tiziana Assenza } \\
\text { Alberto Cardaci } \\
\text { Domenico Delli Gatti }\end{array}$ & $\begin{array}{l}\text { Perceived wealth, cognitive sophistication } \\
\text { and behavioral inattention }\end{array}$ \\
\hline $134 / 2019$ & Helmut Siekmann & $\begin{array}{l}\text { The Asset Purchase Programmes of the } \\
\text { ESCB - an interdisciplinary evaluation }\end{array}$ \\
\hline $133 / 2019$ & $\begin{array}{l}\text { Josefine Quast } \\
\text { Maik Wolters }\end{array}$ & $\begin{array}{l}\text { Reliable Real-time Output Gap Estimates } \\
\text { Based on a Modified Hamilton Filter }\end{array}$ \\
\hline $132 / 2019$ & $\begin{array}{l}\text { Galina Potjagailo } \\
\text { Maik Wolters }\end{array}$ & Global Financial Cycles since 1880 \\
\hline
\end{tabular}




\section{1 / 2019 Philipp Lieberknecht Volker Wieland}

$130 / 2019 \quad$ Eduard Hofert

129 / $2018 \quad$ Olga Goldfayn-Frank Johannes Wohlfart

$128 / 2018$

127 / 2018

$126 / 2018$

$125 / 2018$

$124 / 2018$

$123 / 2018$

122 / 2018

$121 / 2018$

$120 / 2017$

Helmut Siekmann

119 / 2017 Gregor Boehl

$118 / 2017$

117 / 2017

$116 / 2017$

Christopher Roth Johannes Wohlfart

Michael Haliassos

Thomas Jansson

Yigitcan Karabulut

Felix Strobel

Alexander Meyer-Gohde

Daniel Neuhoff

Athanasios Orphanides

Karl-Heinz Tödter

Gerhard Ziebarth

Helmut Siekmann

Maik H. Wolters

Gregor Boehl

Thomas Fischer

Tobias H. Tröger

Tobias H. Tröger

$115 / 2017$
Guenter W. Beck

Volker Wieland
On the Macroeconomic and Fiscal Effects of the Tax Cuts and Jobs Act

Regulating Virtual Currencies

How Do Consumers Adapt to a New

Environment in their Economic

Forecasting? Evidence from the German

Reunification

How Do Expectations About the Macroeconomy Affect Personal

Expectations and Behavior?

Financial Literacy Externalities

The Government Spending Multiplier, Fiscal Stress and the Zero Lower Bound

Generalized Exogenous Processes in DSGE: A Bayesian Approach

The Boundaries of Central Bank Independence: Lessons from Unconventional Times

Zinsen, Effektivpreise und Lebenskosten

- Ein Beitrag zur Konstruktion eines intertemporalen Preisindex

Legal Tender in the Euro Area

How the Baby Boomers' Retirement Wave Distorts Model-Based Output Gap

Estimates

Die Einstandspflicht der Bundesrepublik

Deutschland für die Deutsche

Bundesbank und die Europäische

Zentralbank

Monetary Policy and Speculative Stock Markets

Can Taxation Predict US Top-Wealth

Share Dynamics?

Why MREL Won't Help Much

Too Complex to Work - A Critical

Assessment of the Bail-in Tool under the

European Bank Recovery and Resolution Regime

How to Normalize Monetary Policy in the Euro Area 